\title{
Immune normalization strategy against suboptimal health status: safe and efficacious therapy using mixed-natural killer cells
}

\author{
Ying $\mathrm{Li}^{1,2}$, ODA Harunori ${ }^{1,3}$, Shihu $\mathrm{Fu}^{1}$, Fuyuan $\mathrm{Xing}^{1}$, Huawan $\mathrm{Wu}^{1}$, Juan Wang ${ }^{1}$, Aihua Chen ${ }^{1}$, \\ Xinhua Ren ${ }^{1}$, Dawei Peng ${ }^{1}$, Xia Ling ${ }^{1,3, \&}$, Ming Shi ${ }^{2}$, Hongjin $\mathbf{W u}^{1}$ \\ ${ }^{1}$ International Research Center for Regenerative Medicine, BOAO International Hospital, Qionghai 571434, \\ Hainan, China \\ ${ }^{2}$ School of Life Science and Technology, Harbin Institute of Technology, Harbin 150001, Heilongjiang, China \\ ${ }^{3}$ Medical Corporation ISHIN-KAI ODA Clinic, Shinjuku-ku 169-0072, Tokyo, Japan
}

Correspondence to: Xia Ling, Ming Shi, Hongjin Wu; email: lingxiajp@gmail.com, shiming@hit.edu.cn, wuhongiin@hit.edu.cn Keywords: immune cell therapy, natural killer cells, CD16, CD56, PD-1

Received: November 28, $2020 \quad$ Accepted: June 19, $2021 \quad$ Published: August 30, 2021

Copyright: (C) $2021 \mathrm{Li}$ et al. This is an open access article distributed under the terms of the Creative Commons Attribution License (CC BY 3.0), which permits unrestricted use, distribution, and reproduction in any medium, provided the original author and source are credited.

\begin{abstract}
"Immune normalization" has emerged as a new paradigm in immunotherapy, which is proposed in cancer patients instead of conventional "immune-enhancement" therapy. Immune normalization may also be implemented in cancer prevention of "sub-healthy" individuals. We established in vitro cultured mixednatural killer (NKM) cells to achieve immune normalization. The in vitro cytotoxicity of NKM cells was tenfold higher than that of peripheral blood mononuclear cells (PBMCs). The cytotoxicity of NKM cells was negatively correlated with the proportion of T-helper cells (cluster of differentiation: CD3+CD4+ T), and positively correlated with the proportion of NK cells (especially CD56 ${ }^{\text {bright }}$ CD $16^{\text {bright }}$ NK cells). Then, we defined "sub-healthy individuals" after measuring Programmed cell death protein-1 (PD-1) expression in PBMCs from 95 donors aged $>50$ years. Furthermore, we evaluated the potential clinical application of NKM-cell therapy in $\mathbf{1 1}$ patients with malignant lymphoma, one patient with pancreatic cancer, and four sub-healthy individuals. NKM-cell therapy elicited good tolerance and side-effects were not found. In subhealthy individuals, the proportion of $\mathrm{CD} 3^{+} \mathrm{PD}-1^{+} \mathrm{T}$ cells and $\mathrm{CD} 3^{+} \mathrm{CD} 8^{+} \mathrm{PD}-1^{+} \mathrm{T}$ cells was reduced significantly after NKM-cell treatment. We demonstrated that a new method using NKM cells was safe and efficacious as adjuvant treatment for cancer patients as well as therapy for sub-healthy individuals. Normalization of the peripheral immune system through NKM-cell therapy could expand its scope of application in different disorders.
\end{abstract}

\section{INTRODUCTION}

The immune system is a crucial barrier for the human body to resist diseases. Its ability has rhythmic fluctuations [1, 2], and is affected by several factors (e.g., genetic, age [3, 4]). Reduction in the response capacity of immune cells can lead to diseases (e.g., cancer), whereas excessive activation of immune cells can cause autoimmune diseases. Thus, balance in the immune system is important for health [5].
Recently, the concept of "immune normalization" in cancer therapy was investigated by Chen and colleagues [6]. If individual immunity can be normalized, various diseases may be prevented. The development of cell therapy in the past decade has provided hope that this strategy may work. Cell therapies, especially those using immune cells, have been used for cancer treatment, such as therapy using natural killer (NK) cells [7] and chimeric antigen receptor T-cells [8]. 
In recent decades, epidemiological data for colorectal cancer and lung cancer have revealed that prevention and early detection of cancer are far more efficacious than their treatment for controlling cancer mortality $[9$, 10]. Application of immune-cell therapy in disease prevention (especially cancer) can greatly reduce the occurrence or relapse of diseases [11, 12]. For older individuals who may have long-term immunocompromise, immune-cell therapy could "rebalance" their immune system, which would eliminate mutant cells and pathogens (e.g., viruses, bacteria), thereby reducing the disease risk.

Expression of programmed cell death protein (PD)-1 on $\mathrm{T}$ cells has been considered a sign of "immune exhaustion" $[13,14]$. PD-1 expression on peripheralblood mononuclear cells (PBMCs), including cluster of differentiation $(\mathrm{CD}) 4^{+}$and $\mathrm{CD} 8^{+} \mathrm{T}$ cells, has been shown to be increased significantly in cancer [15-20], sarcoidosis [21] and chronic infection with the hepatitisC virus [22]. In 2019, Cortese and colleagues found that in progressive multifocal leukoencephalopathy, PD-1 expression on PBMCs was high and could be reduced significantly after pembrolizumab treatment [23]. Furthermore, in patients suffering from severe coronavirus disease 2019 (COVID-19), in addition to a reduction in the number of peripheral-blood T cells [2428 ], the proportion of PD-1 expression in the remaining T cells is very high $[27,28]$.

We established an in vitro cultured mixed-NK (NKM) cell system using PBMCs and then tested its potential anti-tumor activity in vivo and in vitro. Our data represent the first NKM-cell therapy, and could be used for healthcare and, possibly, cancer treatment.

\section{RESULTS}

\section{Generation and characterization of NKM cells}

To achieve safe and efficacious immunotherapy for patients, we established an in vitro culture system for the production of immune cells without separation or biological additives. The medium used in this culture system was designed specifically for the expansion of NK cells and T cells. Autologous plasma was prepared and inactivated, then used for cell culture. Autologous immune cells were manufactured as shown in Figure 1A and in the Methods and Materials section: these were NKM cells. After the culture was complete, we could obtain $\sim 2.5$ billion immune cells, the main components of which were NK cells and T cells.

We analyzed the immune-cell subsets of NKM cells. The proportion of monocytes $\left(\mathrm{CD} 14^{+}\right)$, B cells $\left(\mathrm{CD} 19^{+}\right)$ and dendritic cells $\left(\mathrm{CD} 11 \mathrm{c}^{+}\right)$was extremely low. In total, 369 NKM cells were analyzed for the distribution of $\mathrm{NK}$ cells $\left(\mathrm{CD} 45^{+} \mathrm{CD} 3^{-} \mathrm{CD} 16 / 56^{+}\right)$and $\mathrm{T}$ cells $\left(\mathrm{CD} 45^{+} \mathrm{CD}^{+}\right)$. NKM cells comprised $\sim 20 \% \mathrm{NK}$ cells $\left(\mathrm{CD}^{-} \mathrm{CD} 16 / 56^{+}\right), \quad \sim 30 \% \quad \mathrm{NK} \quad \mathrm{T}$-like cells $\left(\mathrm{CD}^{+} \mathrm{CD} 16 / 56^{+}\right)$, and other $\mathrm{T}$ cells. Of the $\mathrm{T}$ cells within NKM cells, $\sim 30 \%$ were $\mathrm{T}$ helper $\left(\mathrm{T}_{\mathrm{h}}\right)$ cells $\left(\mathrm{CD}^{+}{ }^{+} \mathrm{CD} 4^{+}\right)$and $50 \%$ were cytotoxic $\mathrm{T}$ cells $\left(\mathrm{CD}^{+} \mathrm{CD}^{+}\right)$(Figure 1B). In PBMCs, NK cells comprised mainly $\mathrm{CD} 3 \mathrm{CD} 16^{+} \mathrm{CD} 56^{\text {neg }} \mathrm{NK}$ cells and $\mathrm{CD} 3^{-} \mathrm{CD} 16^{+} \mathrm{CD} 56^{\mathrm{dim}} \mathrm{NK}$ cells (Supplementary Figure 1A). However, the NK cells from NKM cells mainly comprised $\mathrm{CD} 3{ }^{-} \mathrm{CD} 16^{+} \mathrm{CD} 56^{+} \mathrm{NK}$ cells, of which the main subtype was $\mathrm{CD}^{-} \mathrm{CD} 16^{\text {bright }} \mathrm{CD} 56^{\text {bright }} \mathrm{NK}$ cells (Figure 1C and Supplementary Figure 1B). Furthermore, we analyzed the subpopulations of NK cells from donor-L at different stages of cell culture, including at the primary-culture stage (PBMCs, T75 flask, and T225 flask) and expansion stage $\left(\mathrm{CO}_{2} \mathrm{Bag}\right)$. The main subpopulation of NK cells in PBMCs was CD16 ${ }^{\text {bright }}$ NK cells (Figure 1D). The latter transformed into CD $16^{\mathrm{dim}}$ NK cells upon primary culture (Figure 1E, $1 \mathrm{~F})$, and finally became CD $16^{\text {bright }} \mathrm{CD} 56^{\text {bright }} \mathrm{NK}$ cells after expanded proliferation (Figure 1G).

\section{In vitro cytotoxicity and its correlations with the subpopulation of NKM cells}

We tested the in vitro cytotoxicity of NKM cells on a cancer cell line (K562), and compared its cytotoxicity with that of PBMCs and NK92 cells. In PBMCs (from healthy donors), the mean cytotoxicity was $\sim 7.4 \%$ $($ effector/target $(\mathrm{E} / \mathrm{T})$ ratio $=10: 1,2$-h incubation; $\mathrm{n}=9$ ) and $16.8 \%(\mathrm{E} / \mathrm{T}$ ratio $=10: 1,4-\mathrm{h}$ incubation; $\mathrm{n}=28)$. The mean cytotoxicity of NKM cells $(\mathrm{n}=198)$ that we manufactured was $\sim 65.6 \%$ (E/T ratio $=10: 1,2-\mathrm{h}$ incubation), which was almost tenfold higher than that of PBMCs (Figure 2A and Supplementary Table 1). Approximately $84 \%$ of NKM cells showed $>40 \%$ cytotoxicity. Even with more effector cells and longer incubation times, the cytotoxicity of PBMCs remained far inferior to that of NKM cells (Figure 2B, 2C). Then, the cytotoxicity of NK92 cells was investigated with different E/T ratios (Supplementary Figure 2A). We discovered that the cytotoxicity of NKM cells (E/T ratio $=10: 1)$ was comparable with that of NK92 cells, with an $\mathrm{E} / \mathrm{T}$ ratio of 5:1 (2-h incubation) (Supplementary Figure 2B). Taken together, these results suggested that, although NKM cells had only half the cytotoxicity of that observed in "pure" NK cells (NK92), their cytotoxicity was much higher than that of PBMCs.

NKM cells are a mixed population of cells, so we wondered which subsets of these cells were responsible for in vitro cytotoxicity. We analyzed the subpopulations of NKM cells, and undertook correlation analyses of their in vitro cytotoxicity. We separated 
A

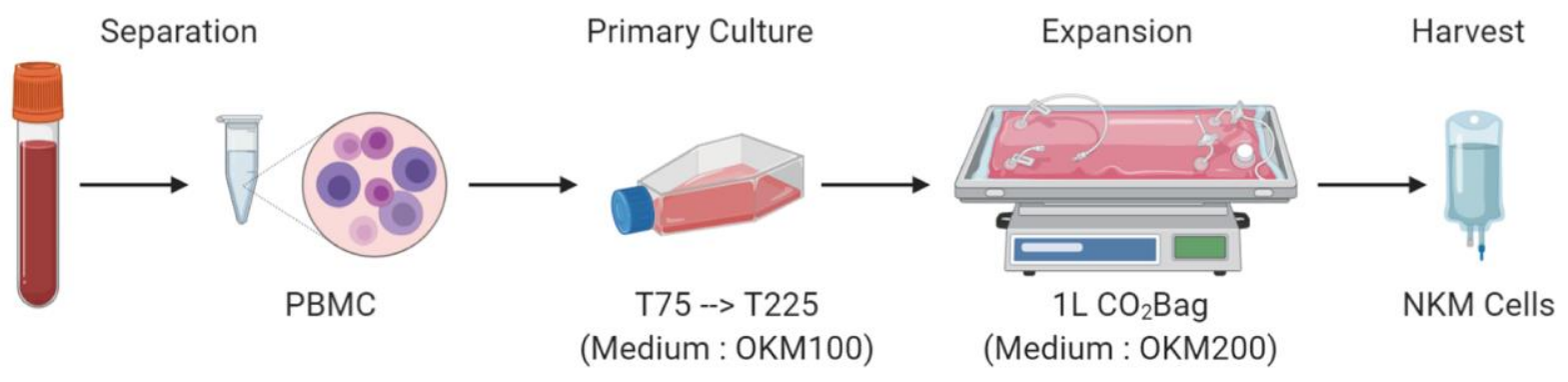

B

NKM: NK\% / NKT-L\%

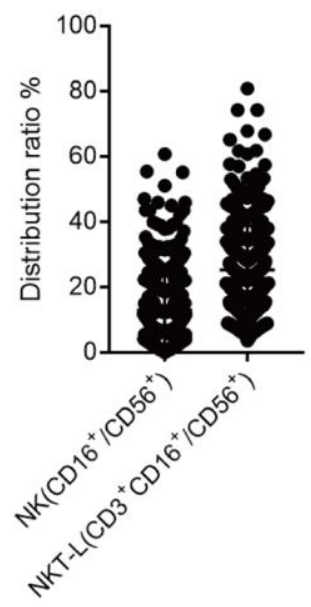

NK cell subpopulation
C

NKM: CD4\% / CD8\%

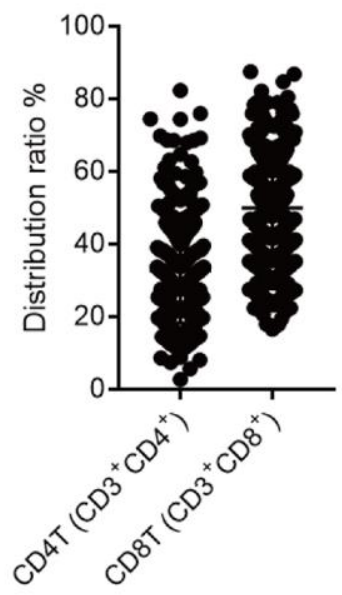

T cell subpopulation

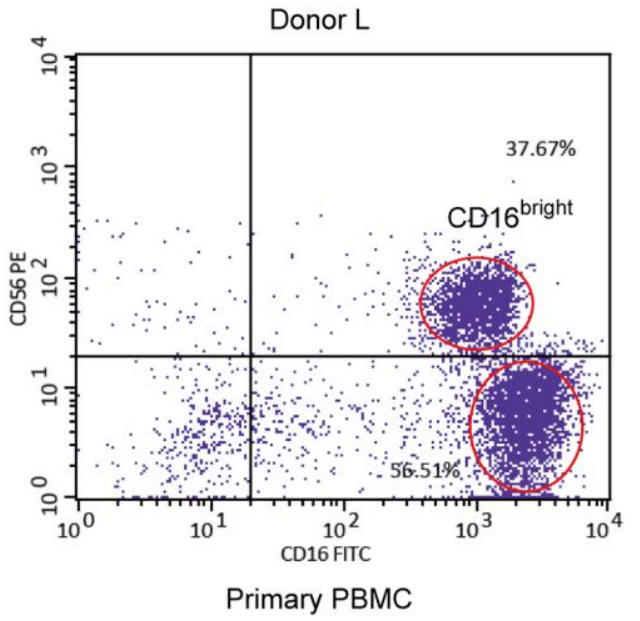

E

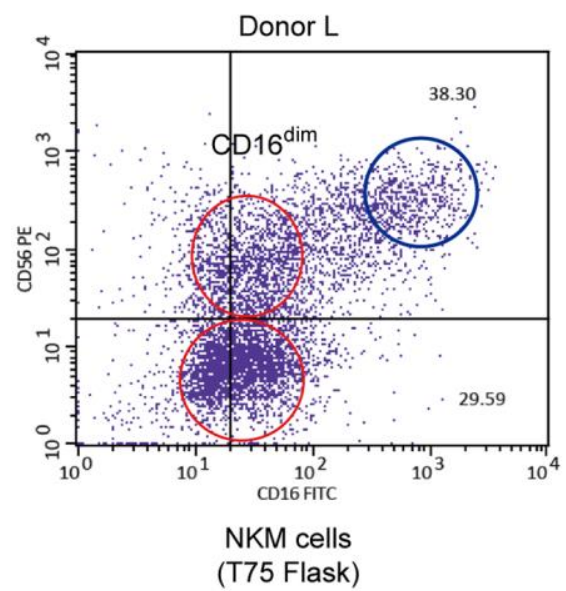

$\mathbf{F}$

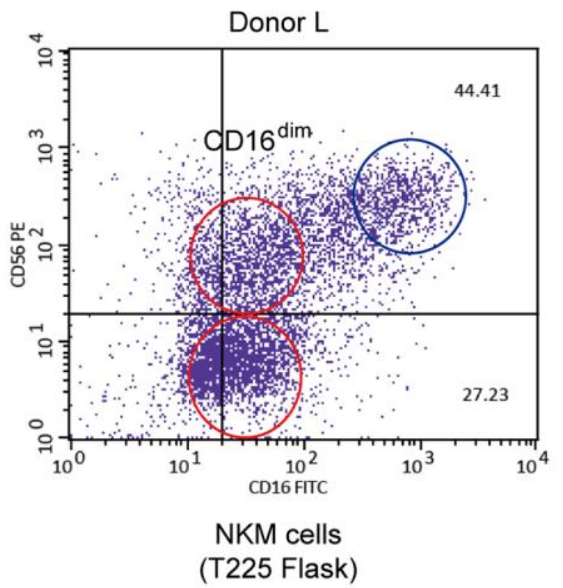

G

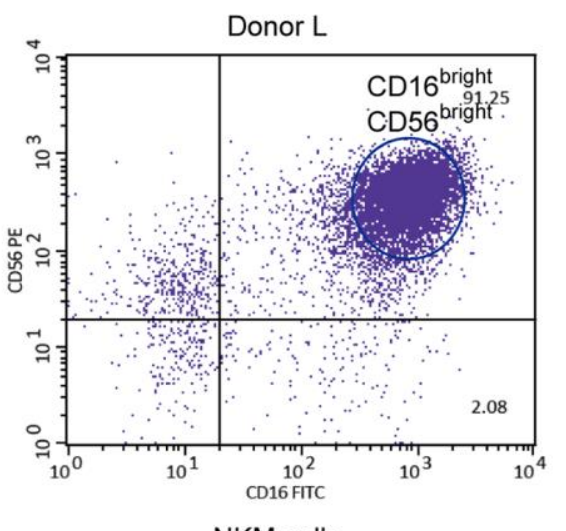

NKM cells

(Final Product)

Figure 1. Characterization of NKM cells. (A) Manufacturing process of NKM cells. The whole process must be carried out in a GMP Laboratory Class A ultra-clean workbench. (B) Composition of NKM cells. (C) The main NK cells in NKM cells were CD16 $6^{\text {bright }}$ CD56 ${ }^{\text {bright }}$ NK cells. The NKM cells from donor-N were analyzed by FACS. The main NKM cells were $\mathrm{CD}^{1} 6^{+} \mathrm{CD} 56^{+}$cells $(87.22 \%)$, whereas the majority was CD16 $6^{\text {bright }}$ CD56 $6^{\text {bright }}$ NK cells. (D-G) NK subpopulations of NKM cells in different culture stages, including primary PBMCs (D), T75 flask (E), T225 flask (F), and NKM product (G). The red circle in primary PBMCs denotes CD16 bright $\mathrm{NK}$ cells, whereas the red circle in T75 and T225 flasks denote CD16 ${ }^{\text {dim }}$ NK cells. The blue circle denotes CD $56^{\text {bright }}$ CD $16^{\text {bright }}$ NK cells. 
NKM cells into $\mathrm{NK}$ cells $\left(\mathrm{CD} 3^{-} \mathrm{CD} 16^{+}\right.$or $\left.\mathrm{CD}^{+} 6^{+}\right), \mathrm{NK}$ T-like cells $\left(\mathrm{CD}^{+}{ }^{+} \mathrm{CD} 16^{+}\right.$or $\left.\mathrm{CD} 56^{+}\right), \mathrm{CD} 4 \mathrm{~T}$ cells $\left(\mathrm{T}_{\mathrm{h}}\right.$ cells, $\mathrm{CD}^{+} \mathrm{CD}^{+}$) or $\mathrm{CD} 8 \mathrm{~T}$ cells (cytotoxic $\mathrm{T}$ cells, $\left.\mathrm{CD}^{+} \mathrm{CD}^{+}\right)$. A strong positive correlation was observed between the cytotoxicity of NKM cells and the proportion of NK cells $(\mathrm{r}=0.58, \mathrm{p}<0.0001)$, but a negative correlation with the proportion of $\mathrm{T}_{h}$ cells was noted $(\mathrm{r}=-0.32, \mathrm{p}<0.0001)$ (Figure 3A, 3C). There was no correlation with the proportion of NK T-like cells and cytotoxic T cells (Figure 3B, 3D).

Furthermore, we divided NK cells into three subpopulations: $\mathrm{CD} 56^{+} \mathrm{CD} 16^{-} \mathrm{NK}$ cells, $\mathrm{CD} 56^{+} \mathrm{CD} 16^{+} \mathrm{NK}$ cells, and $\mathrm{CD} 56^{-} \mathrm{CD} 16^{+} \mathrm{NK}$ cells. The cytotoxicity of NKM cells showed a significant correlation only with CD56 ${ }^{+} \mathrm{CD} 16^{+} \mathrm{NK}$ cells $(\mathrm{r}=0.56, \mathrm{p}<0.0001)$, and no correlation was found in $\mathrm{CD}^{+} 6^{+} \mathrm{CD} 16^{-} \mathrm{NK}$ cells or CD56-CD $16^{+}$NK cells (Figure 3E-3G). Then, we used sorting of immunomagnetic beads to separate different cell subpopulations in NKM cells, and verified them with flow cytometry. We discovered that NK cells isolated from NKM cells showed the highest cytotoxicity (Figure $3 \mathrm{H}$ ), $\mathrm{CD}^{-}$cells, $\mathrm{CD}^{-}$cells and $\mathrm{CD} 8^{-}$cells showed moderate cytotoxicity, and NKnegative cells, $\mathrm{CD}^{+}$cells, $\mathrm{CD}^{+}$cells, and $\mathrm{CD} 8^{+}$cells showed the lowest cytotoxicity (Supplementary Figure $3 \mathrm{~A}-3 \mathrm{C})$.

In addition, we studied the secretion of cytokines in these NKM cells: interleukin (IL)-4, IL-6, IL-10, tumor necrosis factor (TNF)- $\alpha$, and interferon (INF)- $y$. The media from 10 cultured NKM cells were collected and analyzed. The concentration of IL-4, IL-6, IL-10 and TNF- $\alpha$ was very low $(<100 \mathrm{pg} / \mathrm{mL})$, whereas the INF- $\gamma$ concentration was very high $(\sim 300 \mathrm{pg} / \mathrm{mL}$ on average) (Supplementary Figure 4).

Taken together, these data suggested that the in vitro cytotoxicity of NKM cells was caused mainly by the cytotoxicity of $\mathrm{CD}^{2} 6^{+} \mathrm{CD} 16^{+} \mathrm{NK}$ cells, and was suppressed by $\mathrm{T}_{\mathrm{h}}$ cells.

\section{Potential function of NKM cells for adjuvant cancer treatment (in vivo cytotoxicity)}

After the characterization of NKM cells, the potential in vivo anti-tumor activities of NKM cells were investigated in cancer patients for adjuvant cancer therapy. We recruited 11 patients with malignant lymphoma (diffuse large B-cell lymphoma [seven patients], peripheral T-cell lymphoma [two patients], anaplastic large-cell lymphoma [one patient], and Hodgkin's lymphoma [one patient]) who suffered primary relapse/were refractory to treatment (one patient), relapsed after salvage chemotherapy (eight patients), or relapsed after autologous stem-cell therapy (two patients). The treatment process is shown in Figure 4A. Each patient received an intravenous injection of 20-30 $\times 10^{8} \mathrm{NKM}$ cells each time (treatment once every 2 weeks). The response to NKM treatment was not robust (a complete response in one case and stable disease in one case) (Supplementary Table 2), but quality of life was improved greatly. In the patient who had a complete response (case \#2), the number of
A

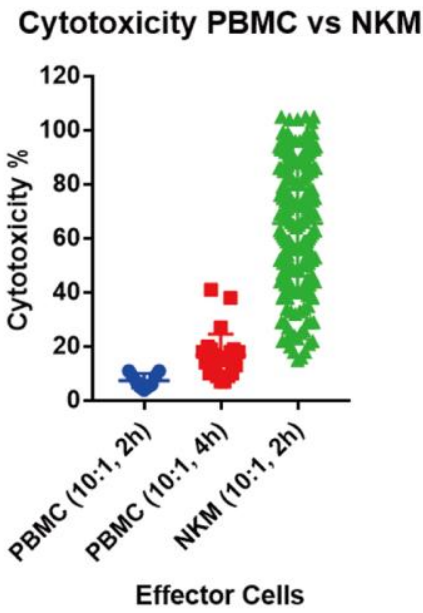

B

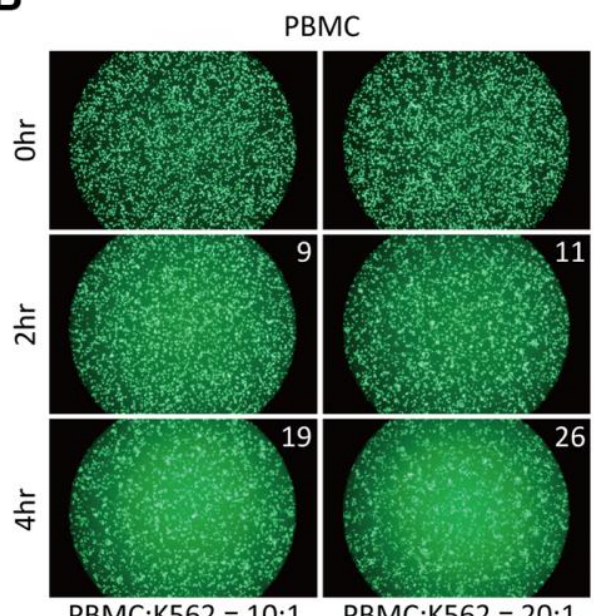

C

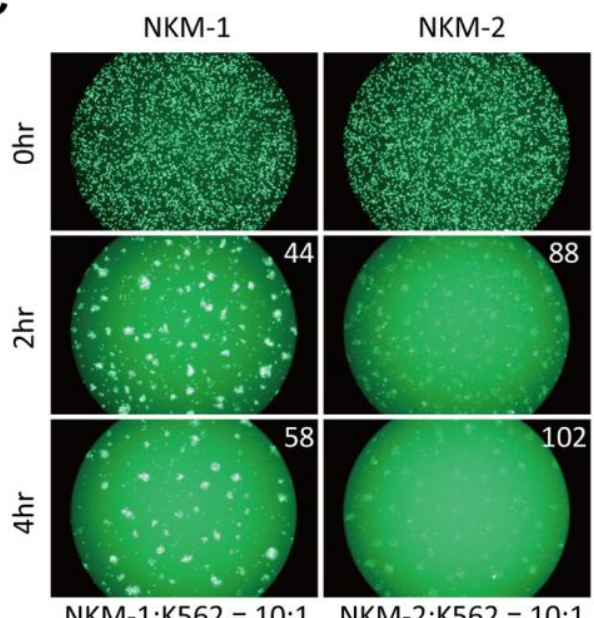

Figure 2. NKM cells have very high in vitro cytotoxicity. (A) The cytotoxicity of PBMCs and NKM cells. The cytotoxicity of 9 PBMCs (incubation for $2 \mathrm{~h}$ ) and 28 PBMCs (incubation for $4 \mathrm{~h}$ ) was obtained. The cytotoxicity of 198 NKM cells (incubation for 2 h) was obtained. (B, C) Labeled target cells (K562 cancer cells) were killed by effector cells (PBMC or NKM). The number on the upper right shows the cytotoxicity of effector cells. The ratio of effector cells: target cells was 10:1 or 20:1, and the incubation time was $2 \mathrm{~h}$ or $4 \mathrm{~h}$. 
cancer foci was reduced significantly after treatment with NKM cells (Figure 4B). During and after intravenous infusion of NKM cells, the body temperature, blood pressure, and heartbeat remained stable, and adverse reactions were not found. The patients tolerated the treatment and clinical side-effects were absent.

Systematic reviews of therapy with NK cells have indicated that immunotherapy with allogeneic NK cells
A

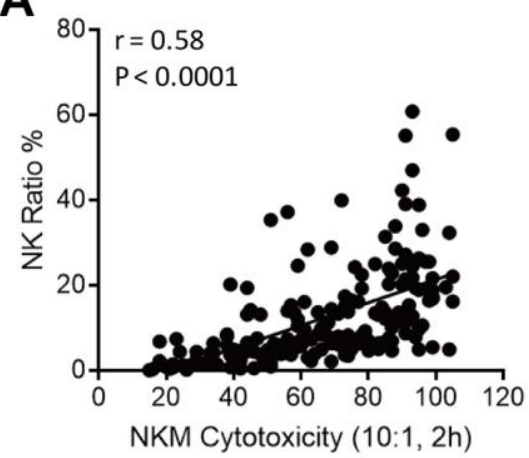

D

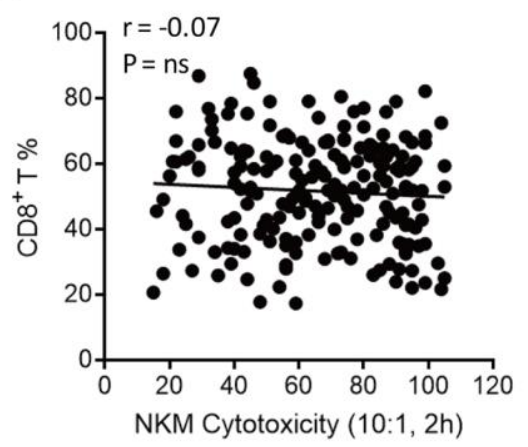

G

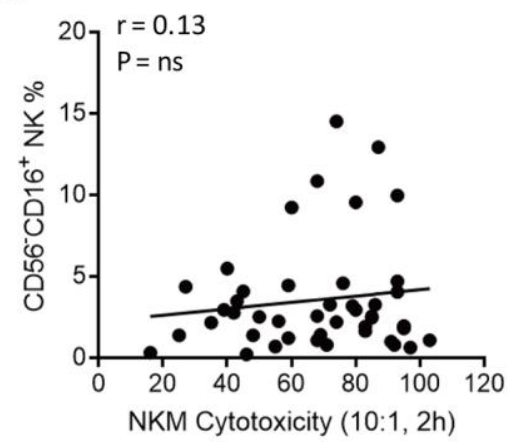

B

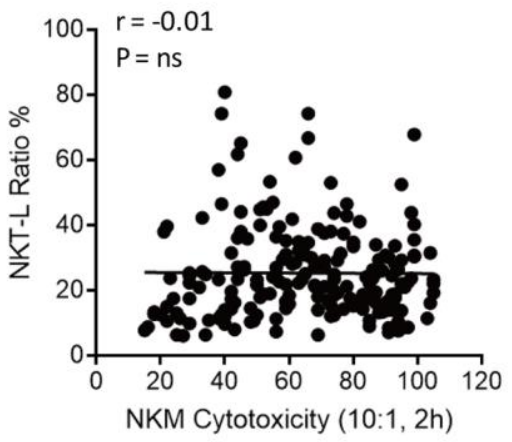

E

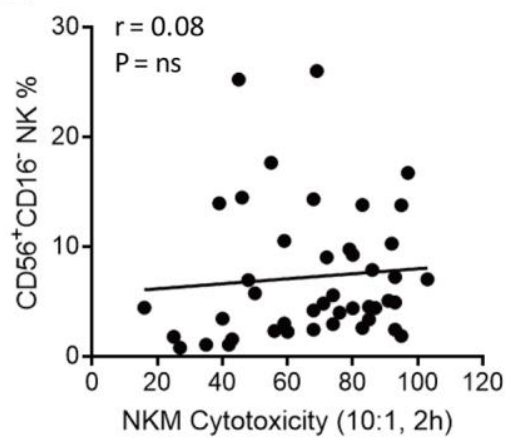

C

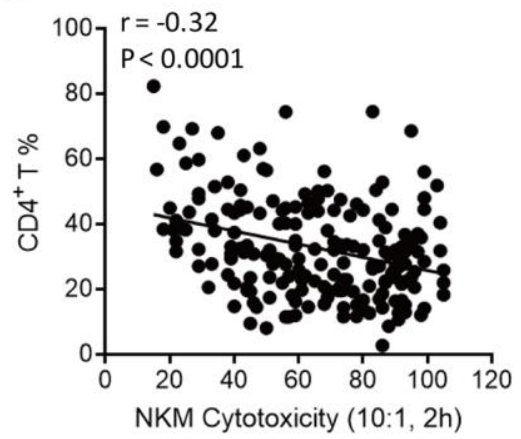

$\mathbf{F}$

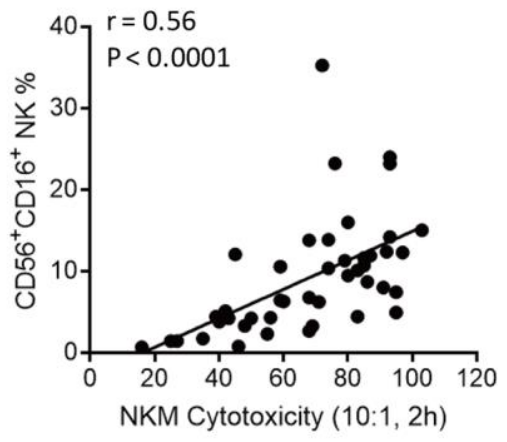

H

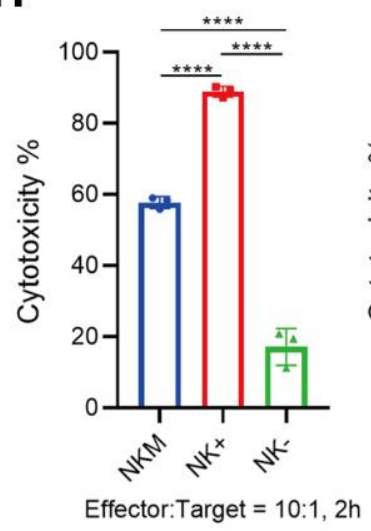

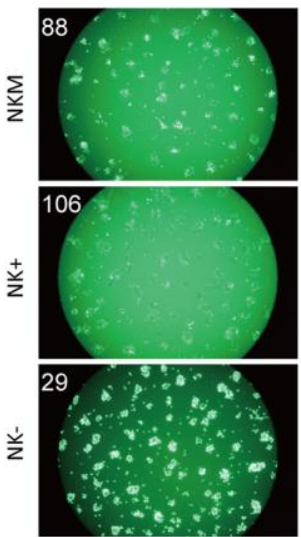

$\mathrm{E}: \mathrm{T}=20: 1,2 \mathrm{~h}$

Figure 3. Correlation of cytotoxicity of NKM cells and cell subpopulations. (A-D) NK cells $\left(C D 3^{-} \mathrm{CD} 16^{+} / \mathrm{CD} 56^{+}\right)$were positively correlated with the cytotoxicity of NKM cells, whereas T-helper cells $\left(\mathrm{CDB}^{+} \mathrm{CD}^{+} \mathrm{T}\right)$ were negatively correlated with the cytotoxicity of NKM cells. A total of 198 NKM cells was used for correlation analyses, and four subpopulations were assessed: NK cells (A), NK T-like cells (B), $\mathrm{CD}^{+} \mathrm{CD}^{+} \mathrm{T}$ cells (C) and $\mathrm{CD}^{+} \mathrm{CD}^{+} \mathrm{T}$ cells (D). Correlations and linear regressions were analyzed with Prism 7.04 (GraphPad). (E-G) $\mathrm{CD}^{-} \mathrm{CD} 16^{+} \mathrm{CD} 56^{+} \mathrm{NK}$ cells were correlated the cytotoxicity of NKM cells. A total of 44 NKM cells was used for correlation analyses, and four subpopulations were evaluated: $\mathrm{CD}_{5} 6^{+} \mathrm{CD} 16^{-} \mathrm{NK}$ cells $(\mathrm{E}), \mathrm{CD}^{+} 6^{+} \mathrm{CD} 16^{+} \mathrm{NK}$ cells $(\mathbf{F})$ and $\mathrm{CD}^{-} 6^{-} \mathrm{CD} 16^{+} \mathrm{NK}$ cells $(\mathbf{G})$. Correlations and linear regressions were analyzed with Prism 7.04 (GraphPad). (H) The cytotoxicity of NKM, NK+ and NK- cells. The NKM cells were separated into $\mathrm{NK}+\left(\mathrm{CD}_{6} 6^{+}\right.$or $\mathrm{CD}_{16} 6^{+} \mathrm{NK}$ cells) and NK- (other non-NK cells) cells with immunomagnetic beads (NK Cell Isolation Kit). The ratio of effector cells: target cells was 10:1 or 20:1, and the incubation time was $2 \mathrm{~h}$. The number on the upper right shows the cytotoxicity of effector cells. 
has better clinical efficacy than that using autologous cells [29-31]. Thus, we recruited another patient with pancreatic ductal carcinoma (T4N1M1c) whose cancer cells had metastasized, and he could not sustain chemotherapy. Then, we treated this patient with a human leukocyte antigen-matched infusion of haploidentical NKM cells (donor was the patient's son). The patient received an intravenous injection of $20-30 \times 10^{8}$

A

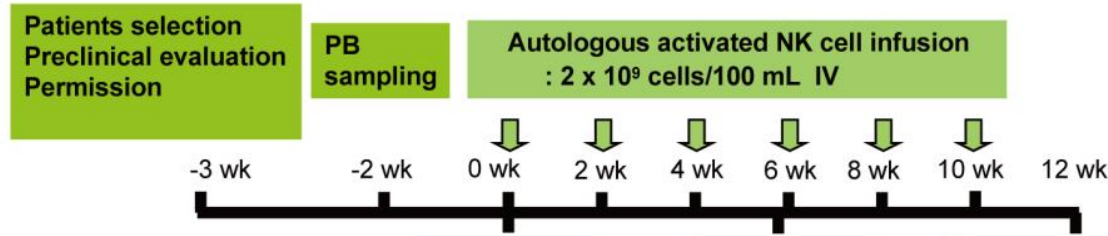

\begin{tabular}{|c|c|c|}
\hline $\begin{array}{l}\text { Initial } \\
\text { evaluation }\end{array}$ & $\begin{array}{l}\text { Response } \\
\text { evaluation }\end{array}$ & $\begin{array}{l}\text { Response } \\
\text { evaluation }\end{array}$ \\
\hline
\end{tabular}

B

Diffuse large B-cell lymphoma patient (Pt.2)

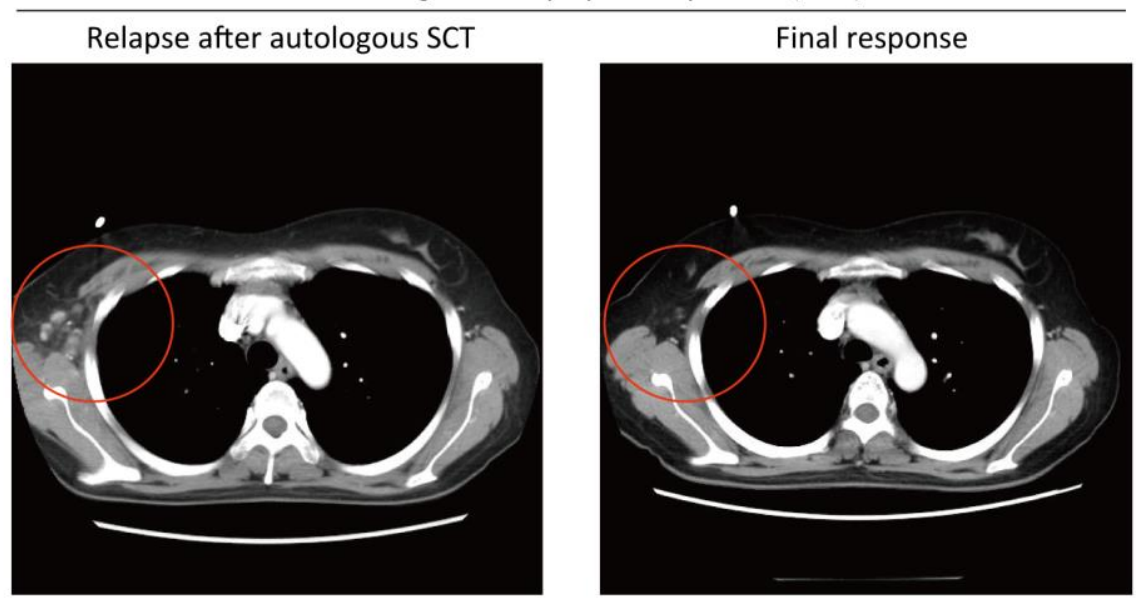

C

Pancreatic ductal carcinoma patient

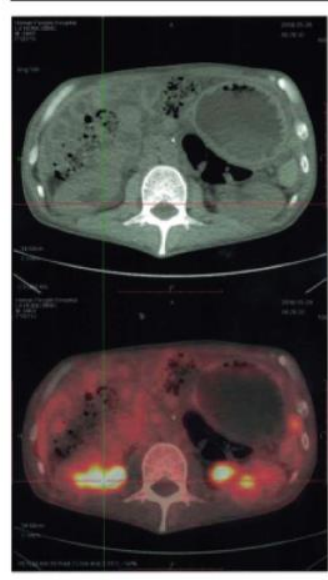

Before Treatment

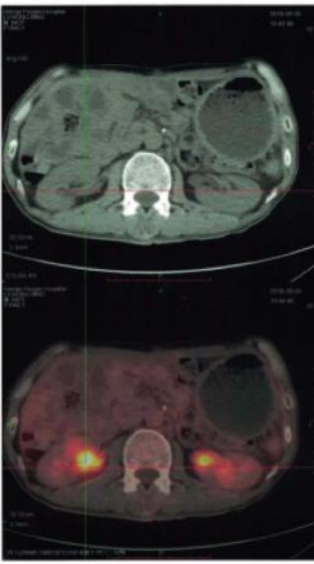

After Treatment

Renal pelvis

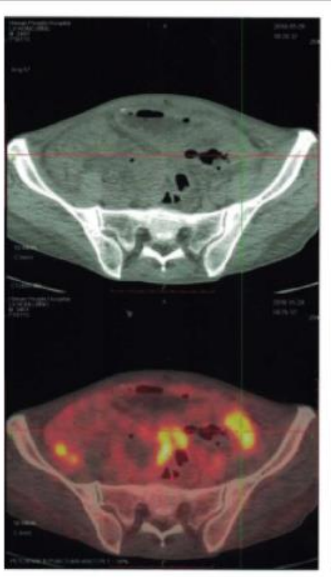

Before Treatment

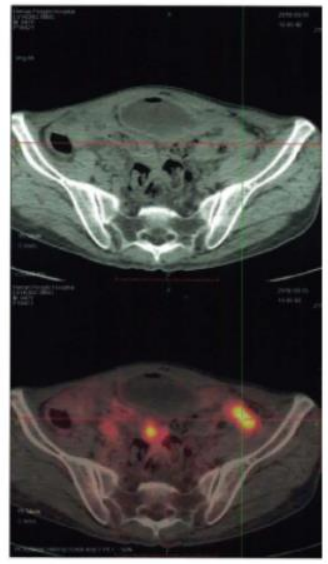

After Treatment

Abdominal pelvic peritoneum

Figure 4. The potential anti-tumor activity of NKM cells. (A) The schedule of NKM-cell therapy for cancer patients. After physical examination, 20-30 $\times 10^{8} \mathrm{NKM}$ cells were used for each injection, and six injections were administered in one course of treatment, with a time interval of 2 weeks. (B) A complete response from a DLBCL patient (Pt. \#2) undergoing NKM-cell treatment. (C) A complete response from a pancreatic-cancer patient to NKM-cell treatment (six treatments, once every week). The number of metastatic foci in the renal pelvis and peritoneum of the abdominal pelvis was reduced significantly after NKM-cell treatment. 
NKM cells every week. After six treatments, the patient showed good toleration of treatment, and the number of metastatic foci in the renal pelvis and abdominal pelvic peritoneum was reduced significantly (Figure 4C). The patient's vital signs and physical status were improved significantly.

Taken together, these results suggested that NKM cells displayed efficacious anti-tumor activity in cancer patients, and suggested that NKM cells could be used for adjuvant cancer therapy.

\section{Identification and recharacterization of sub-healthy individuals on the basis of PD-1 expression in PBMCs}

When analyzing the PBMCs of cancer patients, researchers found that PD-1 expression was significant- ly induced in peripheral immune cells [18, 19, 32-34]. Previously, we found that among adolescents (10-20 years), the proportion of PD $-1^{+} \mathrm{PBMCs}\left(\mathrm{CD} 3^{+} \mathrm{CD} 4^{+} \mathrm{PD}\right.$ $1^{+}$or $\mathrm{CD} 3^{+} \mathrm{CD} 8^{+} \mathrm{PD}-1^{+}$) was very low $(<2 \%)$ (data not shown). However, the proportion of PD $-1^{+}$PBMCs in adults varies greatly, and the proportion in individuals is stable if external intervention is not applied. Here, to identify sub-healthy individuals, we measured expression of PD-1 and cytotoxic $\mathrm{T}$ lymphocyteassociated protein (CTLA)-4 in the NK cells and T cells of PBMCs in 95 individuals aged $>50$ years (Supplementary Table 3). PD-1 was expressed only on $T$ cells, including $T_{h}$ cells and cytotoxic $T$ cells, but not on NK cells, whereas CTLA-4 was not expressed in any PBMCs (Figure 5A, 5B). High expression of PD-1 in T cells may indicate that a large number of $\mathrm{T}$ cells are exhausted $[13,14]$ which, in turn implies an abnormal immune system.
A
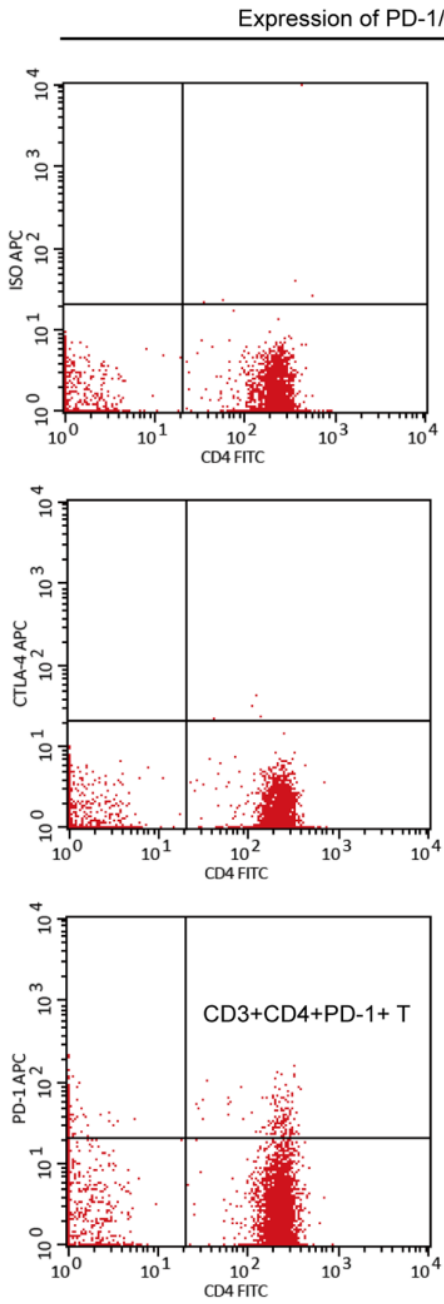
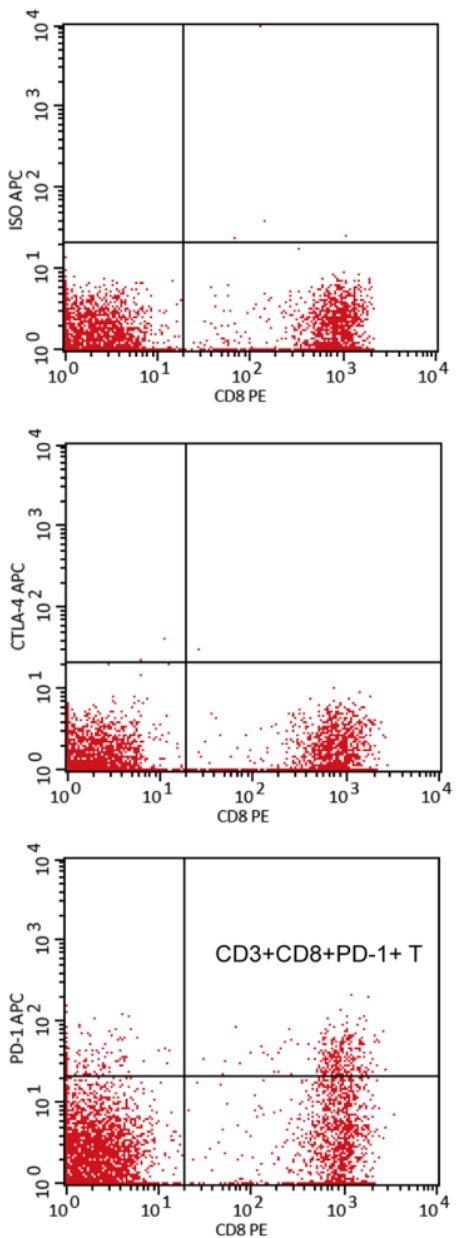

B
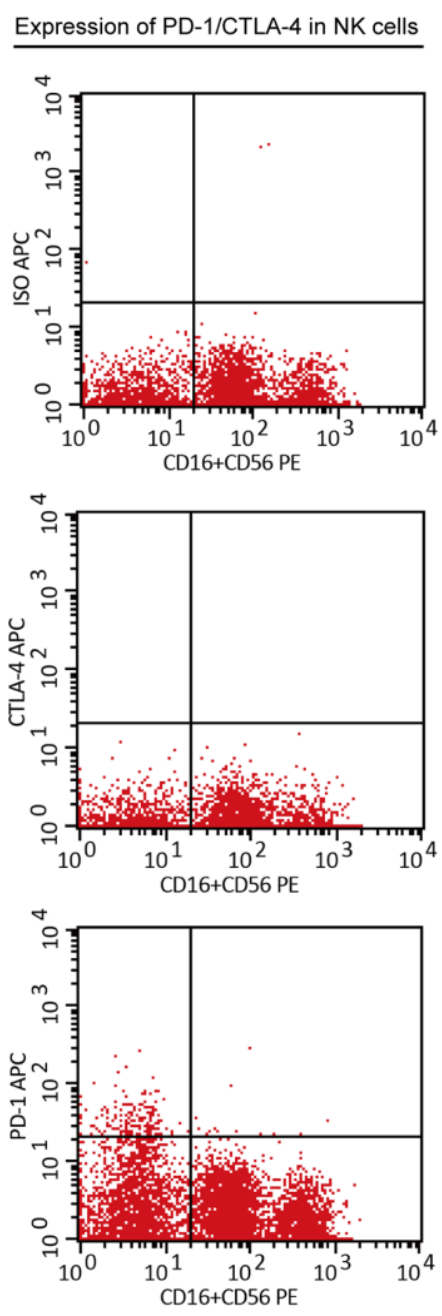

Figure 5. The expression of PD-1 or CTLA-4 in T cells and NK cells of PBMC. (A) PD-1 was expressed on peripheral T cells (including $\mathrm{CD}^{+} \mathrm{CD}^{+}{ }^{+}$cells and $\mathrm{CD}^{+} \mathrm{CD}^{+}{ }^{+}$cells), but CTLA-4 was not. (B) PD-1 and CTLA-4 were not expressed on peripheral NK cells. 
The proportion of $\mathrm{CD} 3^{+} \mathrm{PD}-1^{+}$cells in PBMCs was usually $<4 \%$, and only $16.8 \%$ of individuals had $>4 \%$ of $\mathrm{CD}^{+} \mathrm{PD}-1^{+}$cells in PBMCs (Figure 6A). The proportion of $\mathrm{CD} 3^{+} \mathrm{CD} 4{ }^{+} \mathrm{PD}-1^{+}$cells in $\mathrm{CD} 3^{+} \mathrm{CD} 4^{+} \mathrm{T}$ cells was usually $<10 \%$, and only $9.5 \%$ of individuals had $>10 \%$ of $\mathrm{CD}^{+} \mathrm{CD} 4^{+} \mathrm{PD}-1^{+}$cells in $\mathrm{CD} 3^{+} \mathrm{CD} 4^{+} \mathrm{T}$ cells (Figure 6B). The proportion of $\mathrm{CD} 3{ }^{+} \mathrm{CD} 8^{+} \mathrm{PD}-1^{+}$ cells in $\mathrm{CD}^{+}{ }^{+} \mathrm{CD}^{+} \mathrm{T}$ cells was usually $<10 \%$, and $37.9 \%$ of individuals had $>10 \%$ of $\mathrm{CD}^{+} \mathrm{CD} 8^{+} \mathrm{PD}-1^{+}$ cells in $\mathrm{CD}^{+} \mathrm{CD}^{+} \mathrm{T}$ cells (Figure $6 \mathrm{C}$ ). To define subhealthy individuals, we set the threshold of the ratio of $\mathrm{CD}^{+} \mathrm{PD}-1^{+}$cells/PBMC cells to $>4 \%$ and the threshold of the ratio of $\mathrm{CD} 3^{+} \mathrm{CD} 8{ }^{+} \mathrm{PD}-1^{+}$ cells $/ \mathrm{CD}^{+}{ }^{+} \mathrm{CD} 8^{+}$cells to $>10 \%$. Furthermore, we measured PD-1 expression in NKM cells. The proportion of $\mathrm{CD} 3{ }^{+} \mathrm{PD}-1^{+}$cells and $\mathrm{CD} 3^{+} \mathrm{CD} 4^{+} \mathrm{PD}-1^{+}$ cells was increased in NKM cells, whereas the proportion of $\mathrm{CD} 3^{+} \mathrm{CD} 8^{+} \mathrm{PD}-1^{+}$cells was reduced significantly in NKM cells $(\mathrm{p}<0.0001)$ (Supplementary Figure 5). About $4.2 \%$ of individuals in our cohort showed these characteristics, so the immune system of these people may be abnormal, and we defined these people as "subhealthy individuals".

A
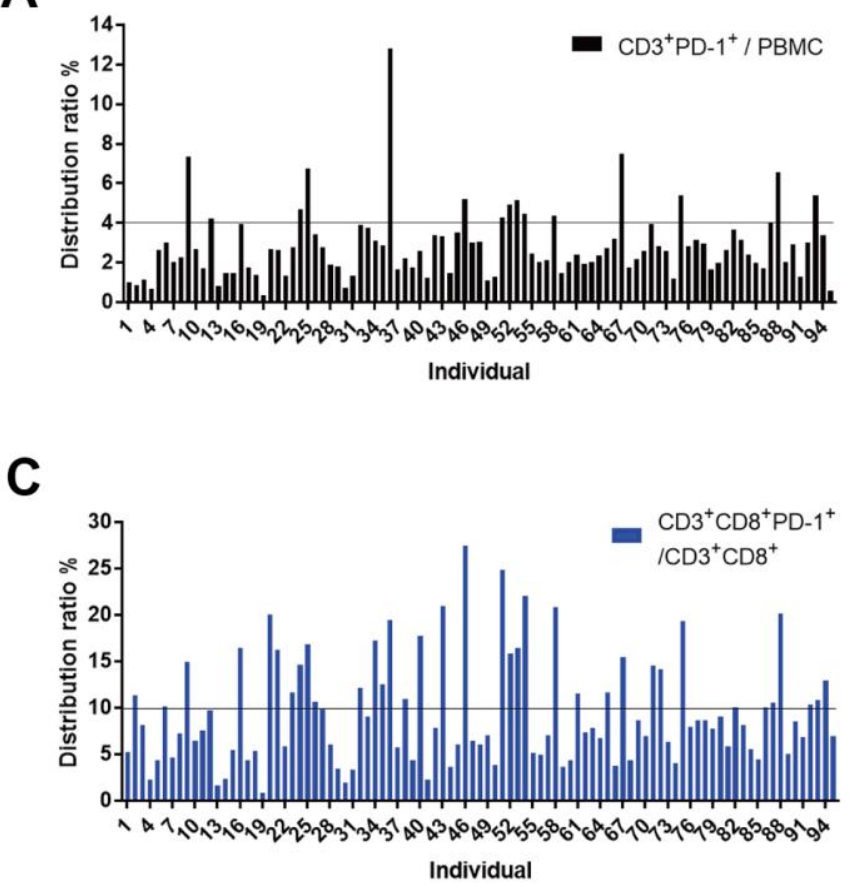

Potential immune normalization of autologous NKM cells in sub-healthy individuals

NKM cells are a mixture of immune-cell types, including $\mathrm{T}_{\mathrm{h}}$ cells (which inhibit cytotoxicity) and NK cells (which elicit cytotoxicity). We wondered if these NKM cells may display more efficacious functions in the immune normalization of sub-healthy individuals.

We recruited four potential sub-healthy individuals and the treatment schedule is shown as Figure 7A. Approximately $20 \times 10^{8}$ autologous NKM cells were used for each treatment. Measurement of PD-1 expression in $\mathrm{T}$ cells was done before treatment, after the first injection, and after the third injection. In Patient-M and Patient- $Z$, upon a single injection of $\mathrm{NKM}$ cells, PD-1 expression in $\mathrm{CD}^{+}, \mathrm{CD}^{+} \mathrm{CD} 8^{+}$, and $\mathrm{CD} 3^{+} \mathrm{CD} 4^{+}$cells could be reduced significantly to a normal level $\left(\mathrm{CD}^{+}{ }^{+} \mathrm{PD}-1^{+}\right.$cells $/ \mathrm{CD}^{+}$cells was $<4 \%$; $\mathrm{CD}^{+}{ }^{+} \mathrm{CD} 4^{+} \mathrm{PD}-1^{+}$cells $/ \mathrm{CD} 3^{+} \mathrm{CD} 4^{+}$cells was $<10 \%$; $\mathrm{CD}^{+}{ }^{+} \mathrm{CD} 8^{+} \mathrm{PD}-1^{+}$cells $/ \mathrm{CD}^{+}{ }^{+} \mathrm{CD}^{+}$cells was $<10 \%$ ) (Figure 7B, 7C). In Patient-J, the effect of one injection of NKM cells was not obvious. After three injections of NKM cells, PD- 1 expression in $\mathrm{CD}^{+}, \mathrm{CD}^{+} \mathrm{CD}^{+}$, and

B

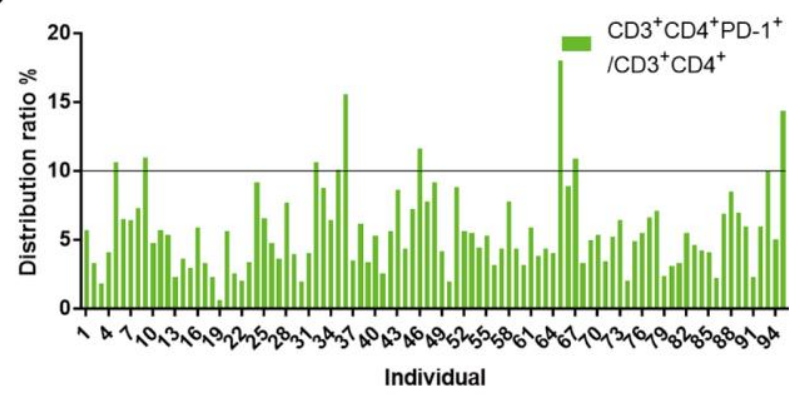

Individual Distribution (A\&B\&C)

CD3+PD-1+ / PBMC $>4 \%: 16.84 \%$

CD3+CD4+PD-1+ / CD3+CD4+ > 10\%: $9.47 \%$

$\mathrm{CD} 3+\mathrm{CD} 8+\mathrm{PD}-1+/ \mathrm{CD} 3+\mathrm{CD} 8+>10 \%: 37.9 \%$

CD3+PD-1+ / PBMC > 4\% \& CD3+CD8+PD-1+ / CD3+CD8+ > $10 \%: 4.21 \%$

Figure 6. Identification of "sub-healthy individuals" with PD-1 expression in PBMCs. (A) Proportion of CD $3^{+}$PD- $1^{+}$cells was $<4 \%$ in the PBMCs of healthy individuals. PBMCs of 95 individuals (aged $>50$ years) were analyzed, of which $16.84 \%$ of samples had a proportion of $\mathrm{CD} 3^{+} \mathrm{PD}-1^{+}$cells $>4 \%$. (B) Proportion of $\mathrm{CD} 3^{+} \mathrm{CD} 4^{+} \mathrm{PD}-1^{+}$cells was $<10 \%$ in the $\mathrm{CD} 3^{+} \mathrm{CD} 4^{+} \mathrm{T}$ cells of healthy individuals. In these 95 individuals, $9.47 \%$ of samples had a proportion of $\mathrm{CD}^{+} \mathrm{CD} 4^{+} \mathrm{PD}-1^{+}$cells $>10 \%$. (C) Proportion of $\mathrm{CD} 3^{+} \mathrm{CD} 8^{+} \mathrm{PD}-1^{+}$cells was $<10 \%$ in the $\mathrm{CD} 3^{+} \mathrm{CD} 8^{+} \mathrm{T}$ cells of healthy individuals. In these 95 individuals, $37.9 \%$ of samples had a proportion of $\mathrm{CD}^{+} \mathrm{CD} 8^{+} \mathrm{PD}-1^{+}$cells $>10 \%$. We defined $\mathrm{CD} 3^{+} \mathrm{PD}-1^{+}$ cells/PBMCs $>4 \%$ and $\mathrm{CD}^{+} \mathrm{CD}^{+}{ }^{+} \mathrm{PD}-1^{+}$cells $/ \mathrm{CD}^{+} \mathrm{CD}^{+}$cell $>10 \%$ as "sub-healthy individuals" (4.21\%). 
$\mathrm{CD} 3^{+} \mathrm{CD} 8^{+}$cells decreased eventually to a normal level (Figure 7D). In Patient-C, three injections of NKM cells reduced PD- 1 expression in $\mathrm{CD}^{+}$cells and $\mathrm{CD}^{+} \mathrm{CD}^{+}$cells, but not in $\mathrm{CD}^{+}{ }^{+} \mathrm{CD} 4^{+}$cells (Figure 7E). All sub-healthy individuals showed good tolerance to treatment, and side-effects were not observed.

In summary, we found that with three therapies with autologous NKM cells, we could reduce PD-1

A

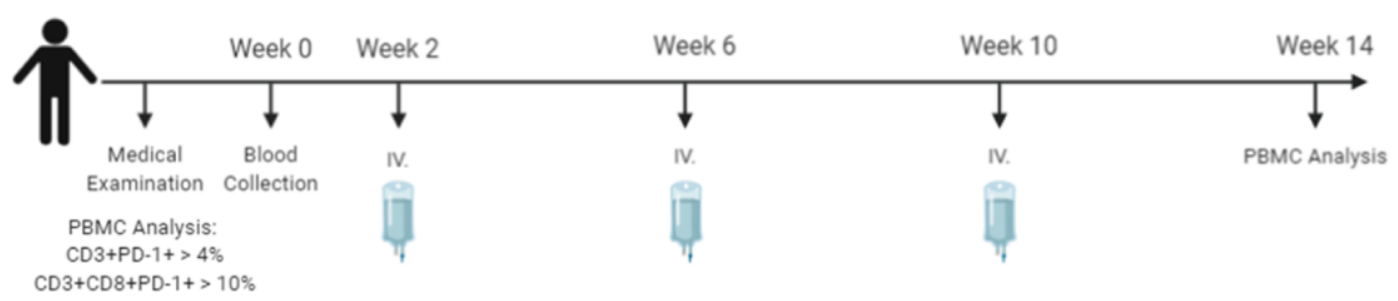

B
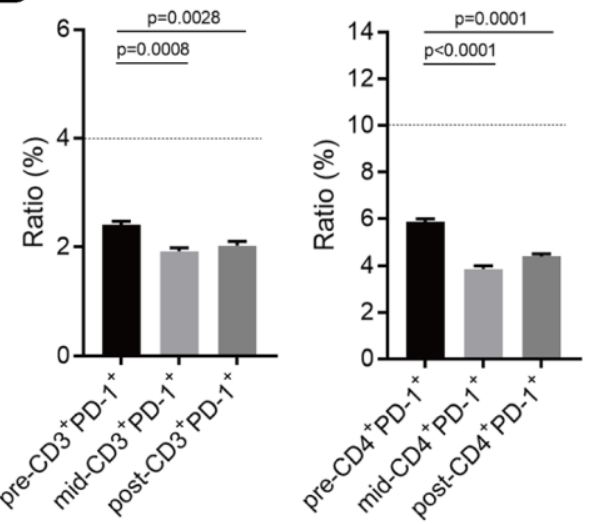

Patient Z
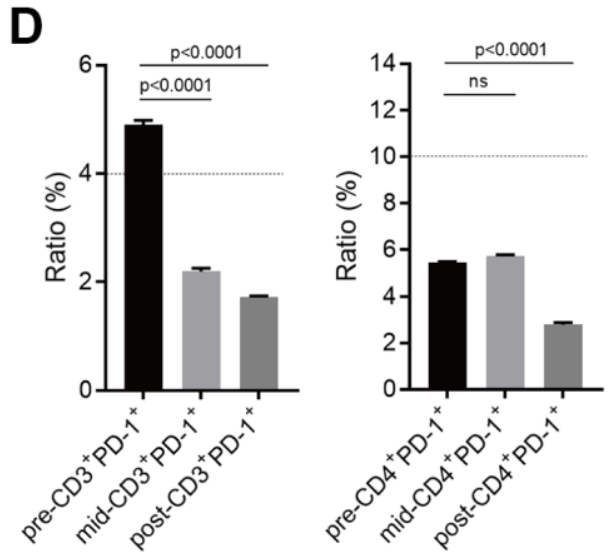

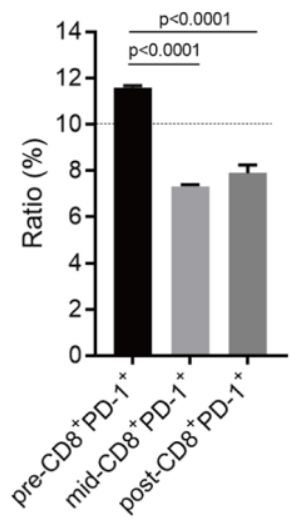

C

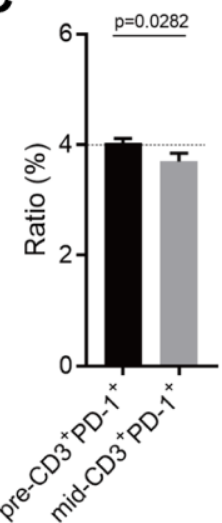

E

Patient J
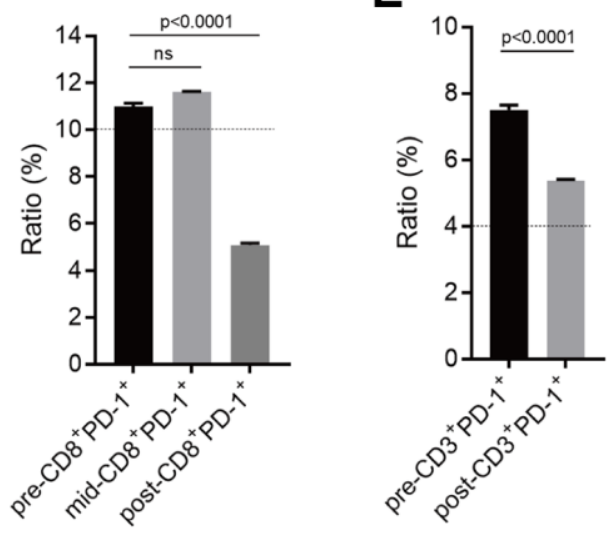

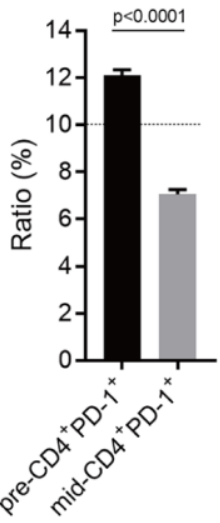

Patient M

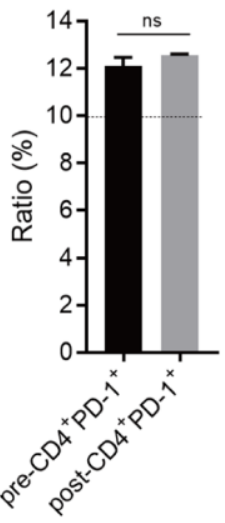

Patient C
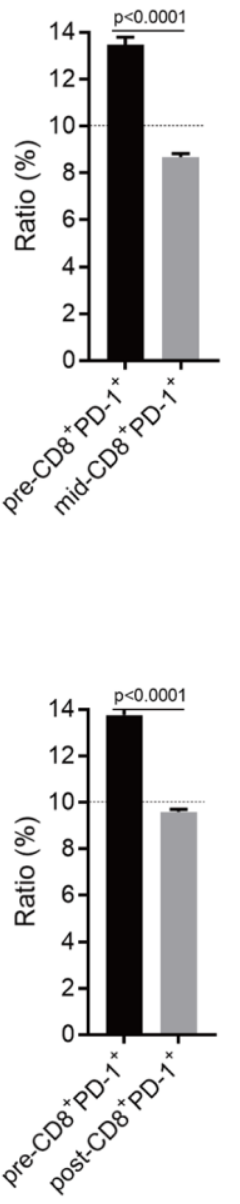

Figure 7. Potential immune normalization using NKM-cell therapy in sub-healthy individuals. (A) The schedule of NKM-cell therapy for sub-healthy individuals. After physical examination, 20-30 $\times 10^{8} \mathrm{NKM}$ cells were used for each injection, and three injections were administered in one course of treatment, with a time interval of 1 month. Detection of the therapeutic effect during NKM-cell treatment was undertaken before the second injection. Detection of the final effect was undertaken 1 month after the end of NKM-cell treatment. (B-E) Efficacious NKM-cell therapy for immune normalization in four sub-healthy individuals. Patient Z (B), Patient M (C), Patient J (D) and Patient C (E) were recruited. Proportions of $C D 3^{+}$PD $-1^{+}$cells/PBMCs and $C D 3^{+} C D 8^{+} P D-1^{+}$cells $/ C D 3^{+} C D 8^{+}$cells were measured before (pre-), during (mid-) and after (post-) NKM-cell treatment. The P-values are shown. 
expression in PBMCs, and achieve renormalization of the immune system in sub-healthy individuals.

\section{DISCUSSION}

For decades, researchers have focused efforts on "enhancing/improving" the immune system to eliminate the potential risks of serious diseases (e.g., cancer). The development of immune-cell therapies have made these concepts a reality.

A safe and efficacious method using NKM cells for the potential adjuvant treatment and prevention of cancer is presented here. We characterized the composition of NKM cells and investigated their cytotoxicity in vitro and in vivo. We showed that NKM cells were significantly cytotoxic to K562 cells or hepatocellular carcinoma cells [35]. However, compared with the number of cancer cells in cancer patients, the number of NKM cells that can reach a cancerous area is relatively small, so the anti-cancer effect is limited. Although the study cohort was and treatment effect was not robust, we showed the potential adjuvant anticancer function of NKM-cell therapy. The latter may not be as efficacious as therapy using pure NK cells. Nevertheless, due to its ease of operation and safety (fewer immune-related side-effects were found), we believe that NKM-cell therapy is potent adjuvant therapy for cancer patients, especially in combination with surgery, to improve the immune response and eliminate residual cancer cells.

Recently, scholars have proposed that cancer immunotherapy should focus on normalization of the immune system [6]. The proportion of PD $-1^{+}$immune cells (exhausted immune cells) is increased in the cancer tissues and PBMCs of cancer patients [13, 20, 23]. We postulate that this abnormality in PD-1 expression in PBMCs may be related to a high risk of cancer. A high proportion of PD- $1^{+} \mathrm{T}$ cells in PBMCs was found in some older adults (4.21\%) in our cohort. Among the subhealthy individuals defined in our research, NKM-cell therapy could reduce PD-1 expression in PBMCs and quickly restore/rebalance the immune system. However, for some individuals (e.g., Patient C), more injections or larger doses of NKM-cell therapy may be required to reduce PD-1 expression in PBMCs.

We expanded NKM-cell therapy to not only treat cancer patients, but also prevent cancer in patients through normalization of the peripheral immune system. NKMcell therapy for sub-healthy individuals must be studied in randomized clinical trials. Our study could be used as reference to expand the number of applications of immune-cell therapy.
The COVID-19 pandemic is wreaking havoc on healthcare and economic systems worldwide. In patients with severe COVID-19, reduction in the number of immune cells and exhaustion of functional $\mathrm{T}$ cells in peripheral blood has been documented [28]. Just like our sub-healthy individuals, PD-1 expression is increased significantly in the $\mathrm{CD} 4^{+} \mathrm{T}$ cells and $\mathrm{CD} 8^{+} \mathrm{T}$ cells of PBMCs in COVID-19 patients. Our experiments in sub-healthy individuals normalized their peripheral immune system, so NKM-cell treatment for COVID-19 patients could be possible.

\section{CONCLUSIONS}

We demonstrated that a new method using NKM cells was safe and efficacious as adjuvant treatment for cancer patients as well as therapy for sub-healthy individuals. Normalization of the peripheral immune system through NKM-cell therapy could expand its scope of application in different disorders.

\section{MATERIALS AND METHODS}

\section{Culture of NKM cells}

NKM cells were manufactured in an ISO Class 5 Good Manufacturing Practice Laboratory within the International Research Center for Regenerative Medicine in BOAO International Hospital (Qionghai, China). Primary PBMCs were separated from whole blood (30-60 mL). A T75 flask was pre-coated with OKM25 medium (Fukoku, Ageo, Japan). PBMCs from individuals were cultured for $3-5$ days in T75 and T225 flasks with OKM100 medium containing $1750 \mathrm{JRU} / \mathrm{mL}$ of IL-2 (Fukoku) and $10 \%$ autologous inactivated plasma. Then, NKM cells were transferred to a $\mathrm{CO}_{2}$ Bag containing $1 \mathrm{~L}$ of OKM200 medium (containing $175 \mathrm{JRU} / \mathrm{mL}$ of IL-2) (Fukoku) and 1\% autologous inactivated plasma, followed by culture for 3-5 days. NKM cells were incubated at $37^{\circ} \mathrm{C}$ in a humidified incubator in an atmosphere of and $5 \% \mathrm{CO}_{2}$.

\section{Ethical approval and consent to participate}

The study protocol was approved by the Medical Ethics Committee of BOAO International Hospital. Sample collection, written informed consent from and recruitment of healthy donors and patients followed Ethics Review Board protocols from BOAO International Hospital (QiongHai, China; approval number of BIH-2018-1001 for adjuvant cancer therapy, and BIH-2018-1002 for care of sub-healthy individuals). The study was conducted according to the principles of the Declaration of Helsinki 1964 and its later amendments. 


\section{Flow cytometry and antibodies}

We wished to analyze the T-cell subpopulations of PBMCs and NKM cells. BD Tritest ${ }^{\mathrm{TM}}$ CD3 fluorescein isothiocyanate (FITC)/CD16 ${ }^{+} \mathrm{CD} 56$ phycoerythrin $(\mathrm{PE}) / \mathrm{CD} 45$ peridinin chlorophyll protein $(\mathrm{PerCP})$ and BD Tritest CD4 FITC/CD8 PE/CD3 PerCP (BD Biosciences, San Jose, CA, USA) were used for flow cytometry. BD Pharmingen ${ }^{\mathrm{TM}}$ PE Mouse Anti-Human CD56 and BD Pharmingen FITC Mouse Anti-Human CD16 (BD Biosciences) antibodies were used for analyses of the NK cell-subpopulations of PBMCs and NKM cells. BD Pharmingen APC Mouse antiHuman CD279, BD Pharmingen APC Mouse AntiHuman CD152, and BD Pharmingen APC Mouse IgG1, $\kappa$ Isotype Control antibodies (BD Biosciences, Shanghai, China) were used for flow cytometry of the PD $-1^{+}$cell and CTLA- $4^{+}$cell subpopulations of PBMCs and NKM cells. Flow cytometry was done according to manufacturer (BD Biosciences) instructions.

\section{Assay to measure cell cytotoxicity}

The cytotoxicity of PBMCs and NKM cells was assessed by measuring the mean fluorescence intensity of Calcein AM (catalog number, C3099; Thermo Fisher Scientific, Waltham, MA, USA) in intact cancer cells using Terascan VPC (Minerva Tech, Tokyo, Japan). Briefly, target cells (cancer cell line K562) were resuspended with Dulbecco's modified Eagle's medium containing $10 \%$ fetal bovine serum, and mixed with $20 \mu \mathrm{L}$ of Calcein $\mathrm{AM}$ at $37^{\circ} \mathrm{C}$ for $30 \mathrm{~min}$ for staining. PBMCs or NKM cells were co-cultured with pre-stained target cells at a particular E:T ratio for $2 \mathrm{~h}$ or $4 \mathrm{~h}$. The mean fluorescence intensity of living target cells was measured. The percent cytotoxicity of cells was calculated using the following formula [35]: \% cytotoxicity $=(1-[$ (average fluorescence of the sample wells - average fluorescence of the maximalrelease control wells)/(average fluorescence of the minimal-release control wells - average fluorescence of the maximal-release control wells)]) $\times 100$.

\section{Sorting of immunological magnetic beads}

Cell subsets of NKM cells were sorted using an NK Cell Isolation Kit (130-092-657) for NK cells, CD3 MicroBeads (130-050-101) for $\mathrm{CD}^{+} \mathrm{T}$ cells, CD4 MicroBeads (130-045-101) for $\mathrm{CD}^{+} \mathrm{T}$ cells, and CD8 MicroBeads (130-045-201) for $\mathrm{CD}^{+} \mathrm{T}$ cells according to manufacturer (Miltenyi Biotec, Bergisch Gladbach, Germany) instructions. Isolated cells (negative and positive) were sorted further with a flow cytometer.
Cytokine analyses with a cytometric bead array (CBA) kit

The cytokines secreted by NKM cells were analyzed by Human Th1/Th2 Cytokine Kit II (551809) from BD Biosciences. NKM cells $\left(\sim 2 \times 10^{9}\right.$ cells $)$ were harvested from $1.5 \mathrm{~L}$ of culture medium. The cytokines in these media were dyed and analyzed by flow cytometry according to the instructions of the CBA-kit supplier. Then, the collected data were analyzed with FCAP Array v3.0 (BD Biosciences).

\section{Statistical analyses}

Experiments were carried out independently in triplicate. Data are the mean \pm SD. Graphs were plotted and analyzed with Prism 7.1 (GraphPad, La Jolla, CA, USA). $\mathrm{P}<0.05$ was considered significant.

\section{Availability of data and material}

All data have been added in the Supplementary Tables.

\section{AUTHOR CONTRIBUTIONS}

H.W. and X.L. designed the study. Y.L., S.F., and F.X. carried out cell cultures. Y.L., Hw.W., J.W., and A.C. carried out the analyses on NKM cells. O.H., X.R., and D.P. recruited patients and collected clinical data. H.W., X.L., and M.S, analyzed the data and undertook statistical analyses. H.W., M.S., and X.L. interpreted and discussed the data with all authors. H.W., and M.S. wrote the manuscript. All authors approved this version of the manuscript.

\section{ACKNOWLEDGMENTS}

The authors thank Mr. Xianyu Li (Jimin Pharmaceuticals) and $\mathrm{Mr}$. Jianguo $\mathrm{Xu}$ (BOAO International Hospital) for providing the GMP Laboratory. This manuscript has been released as a preprint at Research Square (Ying Li et al.) [36].

\section{CONFLICTS OF INTEREST}

The authors declare that they have no conflicts of interest.

\section{FUNDING}

This work was supported by grants from the National Natural Science Foundation of China (81903046 and 31870891), and China Postdoctoral Science Foundation (2020M673596XB). 


\section{Editorial note}

${ }^{\&}$ This corresponding author has a verified history of publications using a personal email address for correspondence.

\section{REFERENCES}

1. Labrecque N, Cermakian N. Circadian Clocks in the Immune System. J Biol Rhythms. 2015; 30:277-90.

https://doi.org/10.1177/0748730415577723 PMID:25900041

2. Scheiermann C, Gibbs J, Ince L, Loudon A. Clocking in to immunity. Nat Rev Immunol. 2018; 18:423-37. https://doi.org/10.1038/s41577-018-0008-4 PMID:29662121

3. Yaqoob P. Ageing alters the impact of nutrition on immune function. Proc Nutr Soc. 2017; 76:347-51. https://doi.org/10.1017/S0029665116000781 PMID:27821203

4. Castañeda-Delgado JE, Frausto-Lujan I, González-Curiel I, Montoya-Rosales A, Serrano CJ, Torres-Juarez F, Enciso-Moreno JA, Rivas-Santiago B. Differences in Cytokine Production during Aging and Its Relationship with Antimicrobial Peptides Production. Immunol Invest. 2017; 46:48-58. https://doi.org/10.1080/08820139.2016.1212873 PMID:27618158

5. Dietert RR, Piepenbrink MS. The managed immune system: protecting the womb to delay the tomb. Hum Exp Toxicol. 2008; 27:129-34. https://doi.org/10.1177/0960327108090753 PMID: 18480137

6. Sanmamed MF, Chen L. A Paradigm Shift in Cancer Immunotherapy: From Enhancement to Normalization. Cell. 2018; 175:313-26.

https://doi.org/10.1016/j.cell.2018.09.035 PMID: $\underline{30290139}$

7. Tarazona R, Lopez-Sejas N, Guerrero B, Hassouneh F, Valhondo I, Pera A, Sanchez-Correa B, Pastor N, Duran E, Alonso C, Solana R. Current progress in NK cell biology and NK cell-based cancer immunotherapy. Cancer Immunol Immunother. 2020; 69:879-99. https://doi.org/10.1007/s00262-020-02532-9 PMID:32130453

8. Wang Z, Wu Z, Liu Y, Han W. New development in CART cell therapy. J Hematol Oncol. 2017; 10:53. https://doi.org/10.1186/s13045-017-0423-1 PMID:28222796

9. Jideh B, Bourke MJ. Colorectal cancer screening reduces incidence, mortality and morbidity. Med J Aust. 2018; 208:483-84. https://doi.org/10.5694/mja18.00279 PMID:29902408

10. Ostrowski M, Marjański T, Rzyman W. Low-dose computed tomography screening reduces lung cancer mortality. Adv Med Sci. 2018; 63:230-36.

https://doi.org/10.1016/j.advms.2017.12.002 PMID:29425790

11. Wagner AK, Alici E, Lowdell MW. Characterization of human natural killer cells for therapeutic use. Cytotherapy. 2019; 21:315-26. https://doi.org/10.1016/i.jcyt.2018.11.001 PMID:30910383

12. López-Soto A, Gonzalez S, Smyth MJ, Galluzzi L. Control of Metastasis by NK Cells. Cancer Cell. 2017; 32: 135-54.

https://doi.org/10.1016/j.ccell.2017.06.009 PMID:28810142

13. Zarour HM. Reversing T-cell Dysfunction and Exhaustion in Cancer. Clin Cancer Res. 2016; 22: 1856-64.

https://doi.org/10.1158/1078-0432.CCR-15-1849 PMID:27084739

14. Blank C, Mackensen A. Contribution of the PD-L1/PD-1 pathway to T-cell exhaustion: an update on implications for chronic infections and tumor evasion. Cancer Immunol Immunother. 2007; 56:739-45. https://doi.org/10.1007/s00262-006-0272-1 PMID: 17195077

15. Zheng $H$, Liu $X$, Zhang J, Rice $S J$, Wagman $M$, Kong $Y$, Zhu L, Zhu J, Joshi M, Belani CP. Expression of PD-1 on CD4+ $T$ cells in peripheral blood associates with poor clinical outcome in non-small cell lung cancer. Oncotarget. 2016; 7:56233-40.

https://doi.org/10.18632/oncotarget.9316 PMID:27191652

16. Zhang W, Bai JF, Zuo MX, Cao XX, Chen M, Zhang Y, Han X, Zhong DR, Zhou DB. PD-1 expression on the surface of peripheral blood $\mathrm{CD}^{+} \mathrm{T}$ cell and its association with the prognosis of patients with diffuse large B-cell lymphoma. Cancer Med. 2016; 5:3077-84. https://doi.org/10.1002/cam4.874 PMID:27709793

17. Waki K, Yamada T, Yoshiyama K, Terazaki Y, Sakamoto S, Matsueda S, Komatsu N, Sugawara S, Takamori S, Itoh K, Yamada A. PD-1 expression on peripheral blood T-cell subsets correlates with prognosis in non-small cell lung cancer. Cancer Sci. 2014; 105:1229-35. https://doi.org/10.1111/cas.12502 PMID:25117757

18. MacFarlane AW 4t, Jillab M, Plimack ER, Hudes GR, Uzzo RG, Litwin S, Dulaimi E, Al-Saleem T, Campbell KS. PD-1 expression on peripheral blood cells increases with stage in renal cell carcinoma patients and is rapidly reduced after surgical tumor resection. Cancer 
Immunol Res. 2014; 2:320-31.

https://doi.org/10.1158/2326-6066.CIR-13-0133

PMID:24764579

19. Saito $H$, Kuroda $H$, Matsunaga $T$, Osaki $T$, Ikeguchi $M$. Increased PD-1 expression on CD4+ and CD8+ T cells is involved in immune evasion in gastric cancer. J Surg Oncol. 2013; 107:517-22.

https://doi.org/10.1002/jso.23281

PMID:23129549

20. Gros A, Parkhurst MR, Tran E, Pasetto A, Robbins PF, Ilyas S, Prickett TD, Gartner JJ, Crystal JS, Roberts IM, Trebska-McGowan K, Wunderlich JR, Yang JC, Rosenberg SA. Prospective identification of neoantigen-specific lymphocytes in the peripheral blood of melanoma patients. Nat Med. 2016; 22: 433-38.

https://doi.org/10.1038/nm.4051 PMID:26901407

21. Braun NA, Celada LJ, Herazo-Maya JD, Abraham S, Shaginurova G, Sevin CM, Grutters J, Culver DA, Dworski R, Sheller J, Massion PP, Polosukhin VV, Johnson JE, et al. Blockade of the programmed death-1 pathway restores sarcoidosis CD4(+) T-cell proliferative capacity. Am J Respir Crit Care Med. 2014; 190:560-71. https://doi.org/10.1164/rccm.201401-01880C PMID:25073001

22. Raziorrouh B, Ulsenheimer A, Schraut $W$, Heeg $M$, Kurktschiev $P$, Zachoval $R$, Jung $M C$, Thimme $R$, Neumann-Haefelin C, Horster S, Wächtler M, Spannagl $M$, Haas $J$, et al. Inhibitory molecules that regulate expansion and restoration of HCV-specific CD4+ T cells in patients with chronic infection. Gastroenterology. 2011; 141:1422-31.

https://doi.org/10.1053/i.gastro.2011.07.004

PMID:21763239

23. Cortese I, Muranski P, Enose-Akahata Y, Ha SK, Smith B, Monaco M, Ryschkewitsch C, Major EO, Ohayon J, Schindler MK, Beck E, Reoma LB, Jacobson S, et al. Pembrolizumab Treatment for Progressive Multifocal Leukoencephalopathy. N Engl J Med. 2019; 380: 1597-605.

https://doi.org/10.1056/NEJMoa1815039

PMID:30969503

24. Chan JF, Yuan S, Kok KH, To KK, Chu H, Yang J, Xing F, Liu J, Yip CC, Poon RW, Tsoi HW, Lo SK, Chan KH, et al. A familial cluster of pneumonia associated with the 2019 novel coronavirus indicating person-to-person transmission: a study of a family cluster. Lancet. 2020; 395:514-23.

https://doi.org/10.1016/S0140-6736(20)30154-9 PMID:31986261

25. Chen G, Wu D, Guo W, Cao Y, Huang D, Wang H, Wang $\mathrm{T}$, Zhang $\mathrm{X}$, Chen $\mathrm{H}$, Yu H, Zhang $\mathrm{X}$, Zhang $\mathrm{M}$, Wu S, et al. Clinical and immunological features of severe and moderate coronavirus disease 2019. J Clin Invest. 2020; 130:2620-29.

https://doi.org/10.1172/JCl137244 PMID:32217835

26. Thevarajan I, Nguyen TH, Koutsakos M, Druce J, Caly L, van de Sandt CE, Jia X, Nicholson S, Catton M, Cowie B, Tong SY, Lewin SR, Kedzierska K. Breadth of concomitant immune responses prior to patient recovery: a case report of non-severe COVID-19. Nat Med. 2020; 26:453-55.

https://doi.org/10.1038/s41591-020-0819-2

PMID:32284614

27. Liu Y, Pan Y, Hu Z, Wu M, Wang C, Feng Z, Mao C, Tan Y, Liu Y, Chen L, Li M, Wang G, Yuan Z, et al. Thymosin Alpha 1 Reduces the Mortality of Severe Coronavirus Disease 2019 by Restoration of Lymphocytopenia and Reversion of Exhausted T Cells. Clin Infect Dis. 2020; 71:2150-57. https://doi.org/10.1093/cid/ciaa630 PMID:32442287

28. Diao B, Wang C, Tan Y, Chen X, Liu Y, Ning L, Chen L, Li M, Liu Y, Wang G, Yuan Z, Feng Z, Zhang $Y$, et al. Reduction and Functional Exhaustion of $T$ Cells in Patients With Coronavirus Disease 2019 (COVID-19). Front Immunol. 2020; 11:827. https://doi.org/10.3389/fimmu.2020.00827 PMID: 32425950

29. Van Audenaerde JR, Roeyen G, Darcy PK, Kershaw MH, Peeters M, Smits EL. Natural killer cells and their therapeutic role in pancreatic cancer: A systematic review. Pharmacol Ther. 2018; 189:31-44.

https://doi.org/10.1016/i.pharmthera.2018.04.003 PMID:29660367

30. Veluchamy JP, Kok N, van der Vliet $\mathrm{HJ}$, Verheul HM, de Gruijl TD, Spanholtz J. The Rise of Allogeneic Natural Killer Cells As a Platform for Cancer Immunotherapy: Recent Innovations and Future Developments. Front Immunol. 2017; 8:631.

https://doi.org/10.3389/fimmu.2017.00631 PMID:28620386

31. Liang S, Xu K, Niu L, Wang X, Liang Y, Zhang M, Chen J, Lin $M$. Comparison of autogeneic and allogeneic natural killer cells immunotherapy on the clinical outcome of recurrent breast cancer. Onco Targets Ther. 2017; 10:4273-81. https://doi.org/10.2147/OTT.S139986 PMID:28894383

32. Shan Z, Liu S, Yang L, Liu Z, Hu Y, Yao Z, Tang Z, Fang L, Quan H. Repertoire of peripheral $T$ cells in patients with oral squamous cell carcinoma. Oral Dis. 2020; 26:885-93.

https://doi.org/10.1111/odi.13311 PMID:32097519

33. Akiyama Y, Nonomura C, Kondou R, Miyata H, Ashizawa T, Maeda C, Mitsuya K, Hayashi N, Nakasu Y, Yamaguchi K. Immunological effects of the anti- 
programmed death-1 antibody on human peripheral blood mononuclear cells. Int J Oncol. 2016; 49: 1099-107.

https://doi.org/10.3892/ijo.2016.3586 PMID:27573705

34. Malaspina TS, Gasparoto TH, Costa MR, de Melo EF Jr, Ikoma MR, Damante JH, Cavassani KA, Garlet GP, da Silva JS, Campanelli AP. Enhanced programmed death 1 (PD-1) and PD-1 ligand (PD-L1) expression in patients with actinic cheilitis and oral squamous cell carcinoma. Cancer Immunol Immunother. 2011; 60:965-74.

https://doi.org/10.1007/s00262-011-1007-5

PMID:21442435

35. Yang Z, Feng J, Xiao L, Chen X, Yao Y, Li Y, Tang Y, Zhang S, Lu M, Qian Y, Wu H, Shi M. Tumor-Derived Peptidoglycan Recognition Protein 2 Predicts Survival and Antitumor Immune Responses in Hepatocellular Carcinoma. Hepatology. 2020; 71:1626-42. https://doi.org/10.1002/hep.30924

PMID:31479523

36. Li Y, Fu S, Xing F, Wu H, Wang J, Chen A, Ren X, Peng D, Ling $X$, Shi $M$, Wu H. Immune Normalization Strategy Against Suboptimal Health Status: Safe and Effective Mixed-Natural Killer Cell Therapy. 2020.

https://doi.org/10.21203/rs.3.rs-35479/v1 


\section{SUPPLEMENTARY MATERIALS}

\section{Supplementary Figures}

A

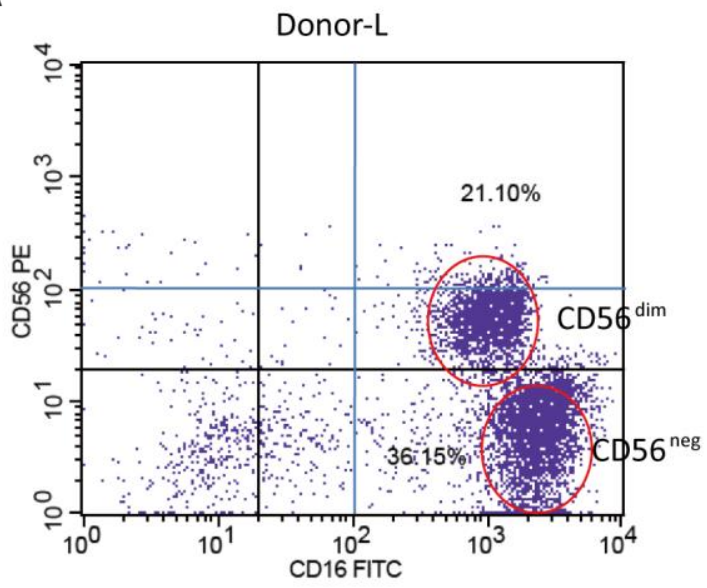

PBMC

B

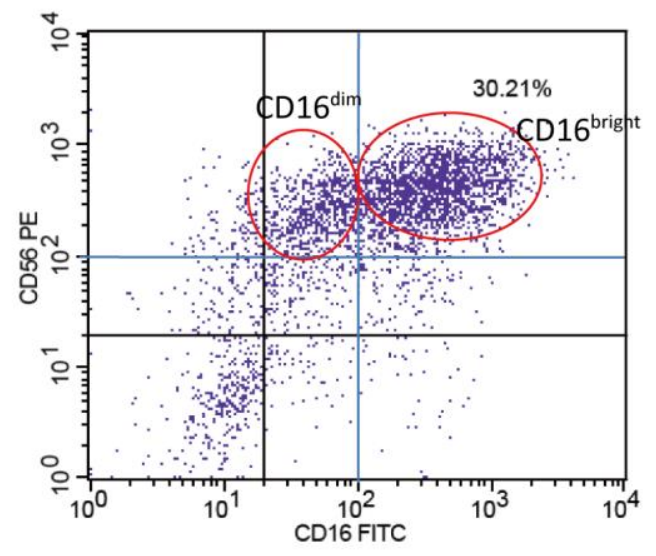

NKM cells

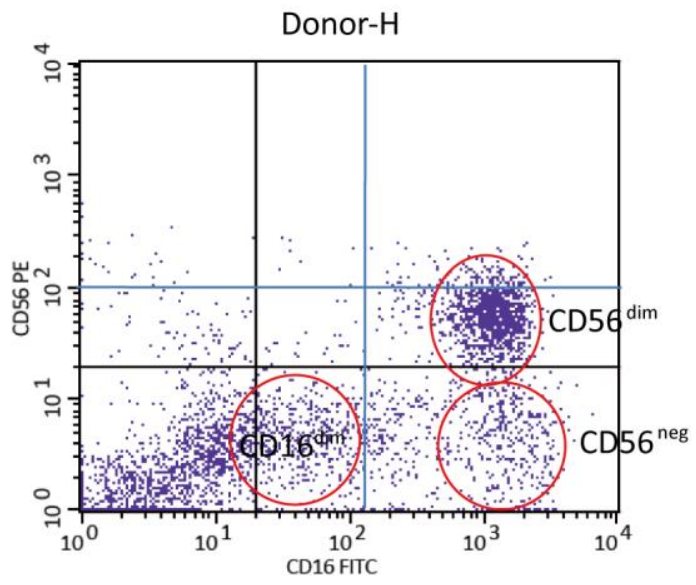

PBMC

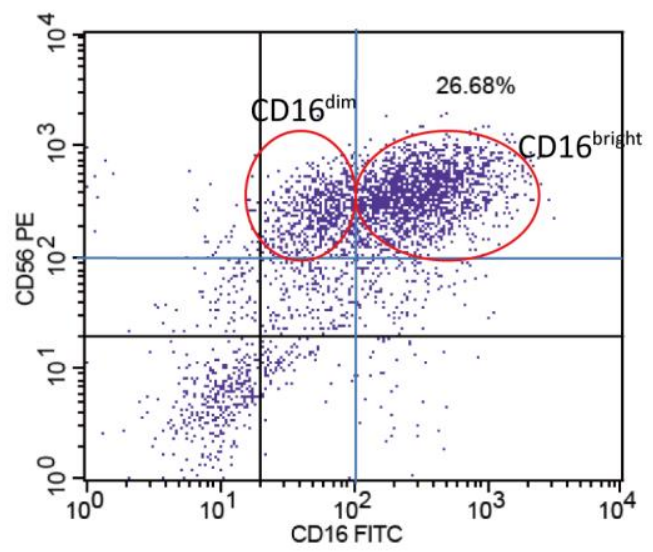

NKM cells

Supplementary Figure 1. The subpopulation of NK cells in PBMC and NKM. (A) The majority of NK cells in PBMC was CD16 bright CD56 $6^{\text {dim/neg }}$ NK cells. In the PBMC of donor-N, NK cells were composed of two main subpopulations: $\mathrm{CD} 16^{\text {bright }}$ CD56 $6^{\text {dim }}$ NK cells and CD16 ${ }^{\text {bright }} C D 56^{\text {neg }}$ NK cells. In the PBMC of donor-H, NK cells were composed of three main subpopulations: CD16 ${ }^{\text {bright }} C D 56^{\text {dim }}$ NK cells, $\mathrm{CD} 16^{\text {bright }} \mathrm{CD} 56^{\text {neg }} \mathrm{NK}$ cells and $\mathrm{CD} 16^{\text {dim }} \mathrm{CD} 56^{\text {neg }} \mathrm{NK}$ cells. (B) The majority of NK cells in NKM was CD16 $6^{\text {bright }} \mathrm{CD} 56^{\text {bright }} \mathrm{NK}$ cells. In the NKM, NK cells were composed of two main subpopulations: $\mathrm{CD} 16^{\text {bright }} \mathrm{CD} 56^{\text {birght }} \mathrm{NK}$ cells and $\mathrm{CD} 16^{\mathrm{dim}} \mathrm{CD} 56^{\text {birght }} \mathrm{NK}$ cells. 
A

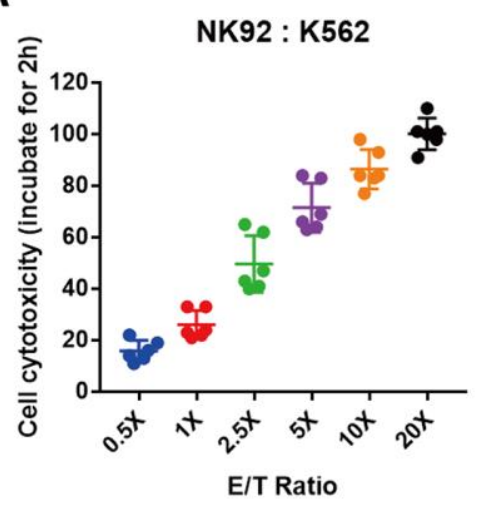

B

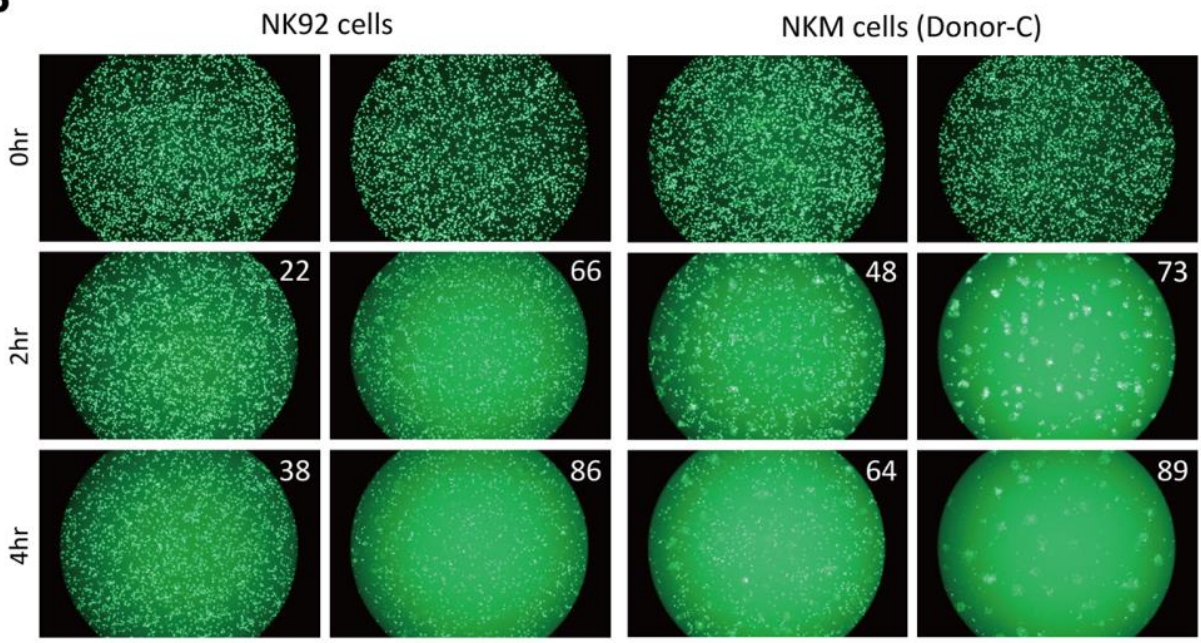

NK92:K562 = 1:1
NK92:K562 = 5:1
NKM:K562 = 5:1

Supplementary Figure 2. The comparison of cytotoxicity between NKM and NK92 cells. (A) Different E/T ratio showed high cytotoxicity of NK92 cells. (B) Labeled target cells (K562 cancer cells) were killed by the effector cells (NKM or NK92). The number on the upper right showed the cytotoxicity of the effector cells. The ratio of effector cells and target cells was 1:1 or 5:1 or 10:1, and the incubation time was $2 \mathrm{~h}$ or $4 \mathrm{~h}$.

A
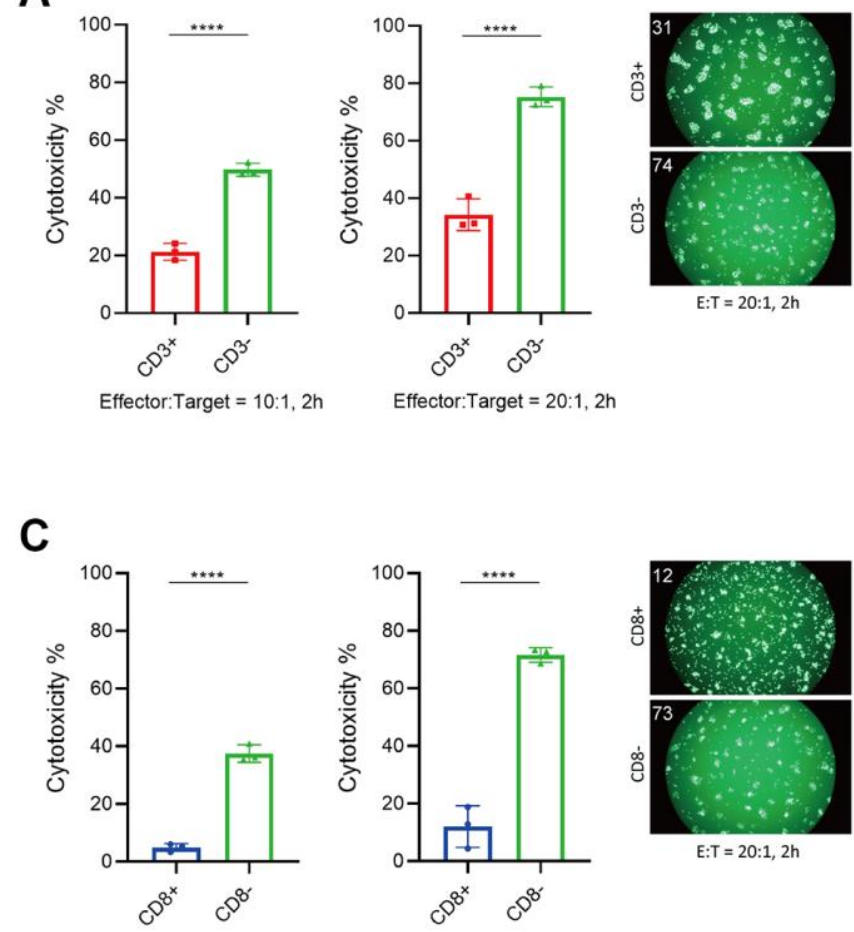

Effector:Target $=10: 1,2 \mathrm{~h}$
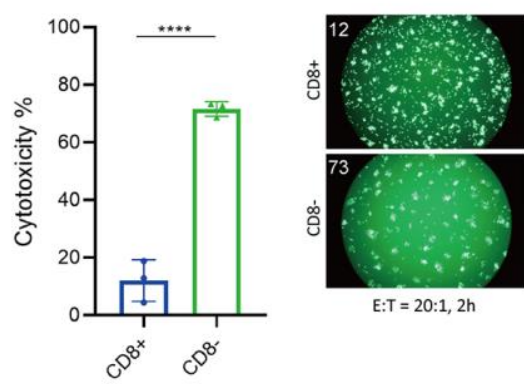

$E: T=20: 1,2 h$
Effector:Target $=20: 1,2 \mathrm{~h}$
B
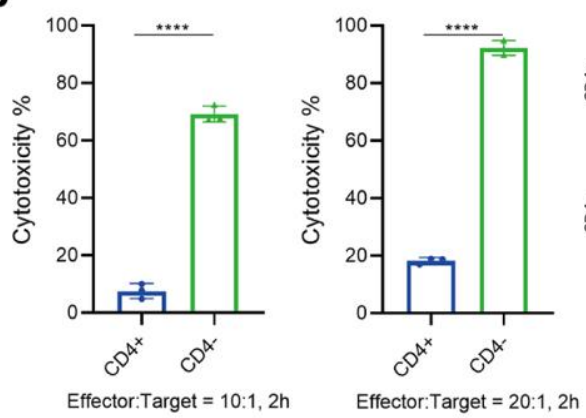

$E: T=20: 1,2 h$

Supplementary Figure 3. The cytotoxicity of CD3+ vs CD3- cells, CD4+ vs CD4- cells, CD8+ vs CD8- cells. (A) The NKM cells were separated into $\mathrm{CD} 3+\left(\mathrm{CD}^{+}\right.$cells) and CD3- (other non-CD3 cells) cells with immunomagnetic beads (CD3 MicroBeads). (B) The NKM cells were separated into $\mathrm{CD} 4+\left(\mathrm{CD} 4^{+}\right.$cells) and CD4- (other non-CD4 cells) cells with immunomagnetic beads (CD4 MicroBeads). (C) The NKM cells were separated into CD8+ (CD8 ${ }^{+}$cells) and CD8- (other non-CD8 cells) cells with immunomagnetic beads (CD8 MicroBeads). The ratio of effector cells: target cells was 10:1 or 20:1, and the incubation time was $2 \mathrm{~h}$. The number on the upper right shows the cytotoxicity of effector cells. 


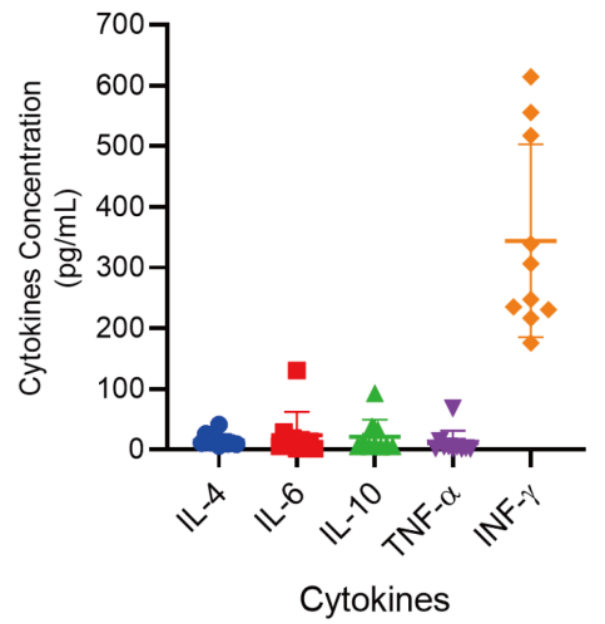

Supplementary Figure 4. The secretion of cytokines in NKM cells. The cytokines: interleukin (IL)-4, IL-6, IL-10, tumor necrosis factor (TNF)- $\alpha$, and interferon (INF)- $\gamma$ were investigated. The media from 10 cultured NKM cells were collected and analyzed.

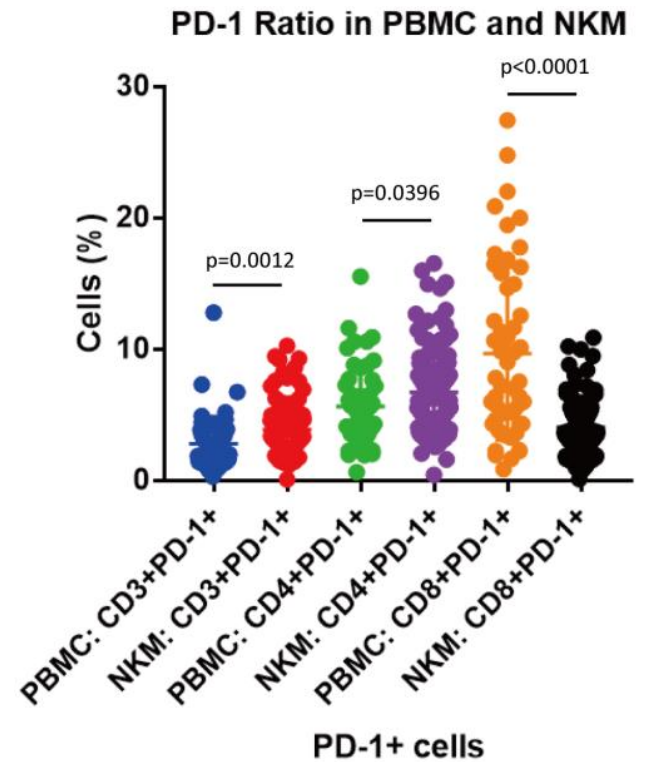

Supplementary Figure 5. The PD-1 expression rate in the subpopulations of NKM cells. The ratio of PD-1 expressing CD3 T cells, CD4 T cells, and CD8 T cells were calculated in our NKM cells. 


\section{Supplementary Tables}

Please browse Full Text version to see the data of Supplementary Tables 1, 3 .

Supplementary Table 1. NKM cytotoxicity and its correlations with the subpopulation of NKM.

Supplementary Table 2. Safety and efficacy of NKM treatment in malignant lymphoma.

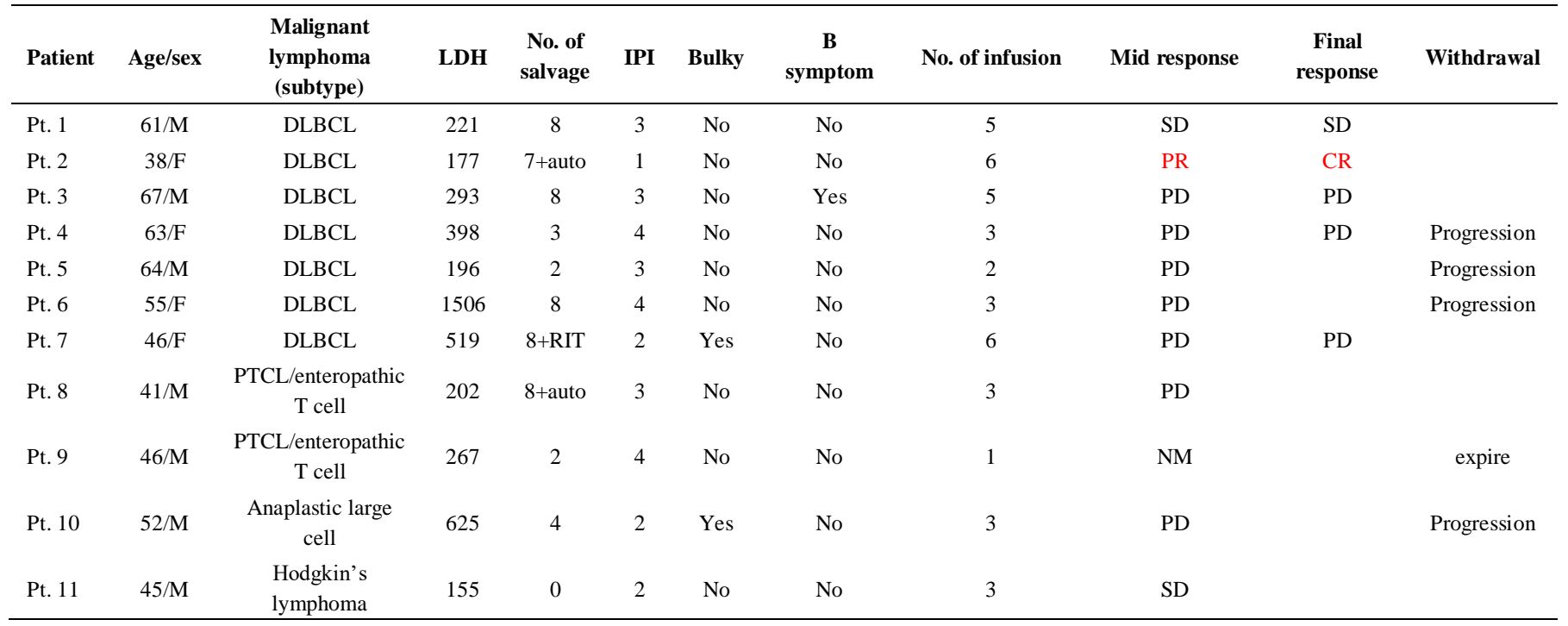

Supplementary Table 3. PD-1 expression in 95 PBMCs. 